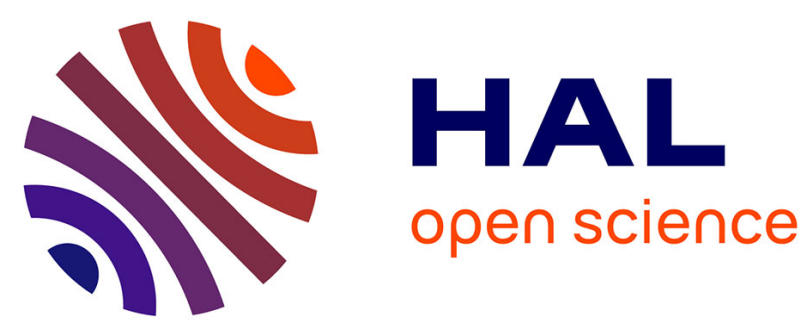

\title{
Molecular and chemical characters to evaluate species status of two cuckoo bumblebees: Bombus barbutellus and Bombus maxillosus (Hymenoptera, Apidae, Bombini)
}

Thomas Lecocq, Patrick Lhomme, Denis Michez, Simon Dellicour, Irena

Valterová, Pierre Rasmont

\section{To cite this version:}

Thomas Lecocq, Patrick Lhomme, Denis Michez, Simon Dellicour, Irena Valterová, et al.. Molecular and chemical characters to evaluate species status of two cuckoo bumblebees: Bombus barbutellus and Bombus maxillosus (Hymenoptera, Apidae, Bombini). Systematic Entomology, 2011, 36 (3), pp.453-469. 10.1111/j.1365-3113.2011.00576.x . hal-01972193

\section{HAL Id: hal-01972193 \\ https://hal.univ-lorraine.fr/hal-01972193}

Submitted on 4 Dec 2020

HAL is a multi-disciplinary open access archive for the deposit and dissemination of scientific research documents, whether they are published or not. The documents may come from teaching and research institutions in France or abroad, or from public or private research centers.
L'archive ouverte pluridisciplinaire HAL, est destinée au dépôt et à la diffusion de documents scientifiques de niveau recherche, publiés ou non, émanant des établissements d'enseignement et de recherche français ou étrangers, des laboratoires publics ou privés. 


\title{
Molecular and chemical characters to evaluate species status of two cuckoo bumblebees: Bombus barbutellus and B. maxillosus (Hymenoptera, Apidae, Bombini)
}

\author{
THOMAS LECOCQ ${ }^{1}$, PATRICK LHOMME ${ }^{1}$, DENIS MICHEZ ${ }^{1}$, SIMON DELLICOUR ${ }^{2}$, IRENA \\ VALTEROVÁ ${ }^{3}$ and PIERRE RASMONT ${ }^{1}$ \\ ${ }^{1}$ Laboratoire de Zoologie, University of Mons, Place du Parc 20, 7000 Mons, Belgium, ${ }^{2}$ Evolutionary Biology and Ecology, Université Libre \\ de Bruxelles, av. FD Roosevelt 50, 1050 Brussels, Belgium, ${ }^{3}$ Institute of Organic Chemistry and Biochemistry, Academy of Sciences of the \\ Czech Republic, Flamingovo nam 2, CZ-166 10 Prague, Czech Republic \\ Corresponding authors: \\ Thomas Lecocq, Laboratoire de Zoologie, University of Mons, B-7000, Mons, Belgium. Phone : 003265373405 . E-mail : \\ thomas.lecocq@umons.ac.be \\ Irena Valterova, Institute of Organic Chemistry and Biochemistry, Academy of Sciences of the Czech Republic, Flamingovo nam 2, CZ-166 \\ 10 Prague, Czech Republic. E-mail: irena@uochb.cas.cz
}

\section{Short Title}

Species discrimination by molecular and chemical evidences

\begin{abstract}
Many methods, based on morphological, molecular or chemical characters, have been used to address the question of species taxonomic status. Integrative taxonomy aims to define stronger supported taxonomic hypotheses by considering complementary datasets from different characters. By following an integrative approach, the present study includes molecular, chemical, and morphological criteria to establish the taxonomic status of two rare and doubtful cuckoo bumblebee taxa, Bombus (Psithyrus) barbutellus and Bombus (Psithyrus) maxillosus. These two sympatric taxa are discriminated by few morphological criteria (mainly wing darkness and hair length). We used these morphological character diagnoses to establish an a priori status of our samples (23 specimens). We developed a combined molecular dataset from one nuclear gene $(\mathrm{EF}-1 \alpha)$ and one mitochondrial gene (COI) spanning $1623 \mathrm{bp}$ and a chemical dataset of sexual marking pheromones (73 compounds). The molecular data were subjected to maximum likelihood and Bayesian phylogenetic inference under partitioned model and maximum parsimony. The chemical data were analysed by clustering and the 2-group k-means method to test divergences between the two species. The resulting phylogenetic trees show no consistent divergence between the two taxa. Moreover, we found no divergence in the sexual marking pheromones in the clustering and 2-group k-means analyses. These converging results support the conspecificity of both taxa. Nonetheless, our determinations using the traditional morphological criteria separated our samples into two taxa. We conclude that the morphological criteria seem to relate to intraspecific variations. B. maxillosus is regarded as a syn.n. of B. barbutellus.
\end{abstract}

\section{Keyword}


Bee taxonomy, Sexual marking pheromones, Phylogeny, Bombus barbutellus, Bombus maxillosus

\section{Introduction}

The species notion is one of the most confusing and controversial concepts in biology (Mayr, 1942; Templeton, 1989; Baum, 1992; De Queiroz, 2007; Gourbière \& Mallet, 2009). However, the species is a fundamental biological unit and its definition is of major importance to biology. Numerous ways have been explored to determine the species status. In hymenopteran systematics (review for bees in Engel, 2011), authors have tried to define taxonomic status using morphology (i.e. Michener, 1951; Pekkarinen, 1982; Williams, 1998), geometric morphometry (i.e. Aytekin et al., 2007), allozyme based models (i.e. Pamilo et al., 1997), genetic (i.e. Koulianous \& Schmid-Hempel, 2000; Hines et al., 2006; Bernasconi et al., 2010), or chemoecology (i.e. Svensson, 1979; Bertsch et al., 2005; Rasmont et al., 2005; Martin et al., 2008 ).

The morphological approach is the earliest, the easiest and the most common method used to define species (i.e. Løken, 1983; Bolton, 1995; Michez \& Eardley, 2007). However, determining objective morphological characters which accurately reflect biological species is difficult (Bickford et al., 2007). Results of morphological analyses have conflicted with other kind of evidences (i.e. Svensson, 1979; Batalha-Filho et al., 2010).

Genetic characters are taken more and more into consideration in order to assess species status (i.e. Leaché \& Fujita, 2010). Development of DNA barcoding studies (i.e. Hebert et al., 2003) to describe cryptic species (i.e. Yassin et al., 2007), or included into integrative taxonomic framework (i.e. Gibbs, 2009) exemplify this trend. A phylogenetic species concept (Baum, 1992) has been developed and defined a species as a monophyletic group (Papadopoulou et al., 2008), perhaps based on multiple gene genealogies (Baum \& Shaw, 1995). Nevertheless, the genetic approach remains controversial in defining species limits 
because DNA sequences analyzed are chosen arbitrarily or because mating isolation can happen faster than differentiation of the genetic markers used (Avise, 2000; Trewick, 2008; Symonds et al., 2009; Bauer et al., 2010).

Chemical features, mainly species specific secretions (i.e. Lockey, 1991), can provide useful tools in separating species. Among bumblebees, Sexual Marking Pheromones (SMP), synthesized by male cephalic labial glands (Kullenberg et al., 1973), play a major role in species specific pre-mating behavior (Bergman, 1997) and are highly species specific (Calam, 1969; Valterova \& Urbanova, 1997). Therefore, authors used these chemical markers in resolving species status (Bergström et al., 1981; Svensson \& Bergström, 1977; Rasmont et al., 2005; Coppée et al., 2008; Lecocq et al., 2009a, 2009b) according to the species recognition concept (Paterson, 1993). In this concept, conspecific individuals sharing the same recognition signals are supposed to recognize each other as sexual partners (review in Terzo et al., 2003). However it is difficult to determine a threshold of species level differentiation, even with ethological test (i.e. Ings et al., 2010). Only B. terrestris has been studied enough to determine a well supported threshold thanks to numerous chemoethological tests (review in Coppée 2010).

The current trend in species limitation studies is to follow a multiple evidence approach (Burns et al., 2008; Fisher \& Smith, 2008; Smith et al., 2008) to differentiate species (i.e. morphological, chemical, molecular, and ecological).

The present study deals with taxonomic problems in the monophyletic subgenus Psithyrus included in the genus Bombus Latreille, 1802. 30 Psithyrus species described worldwide live in the Northern hemisphere (Williams, 1998 update at NHN). Psithyrus species are social parasites (cuckoo bumblebees) of other bumblebees. Cuckoo bumblebees lack pollencollecting corbiculae and a worker caste. They are therefore completely dependent on hosts to rear their offspring. They parasitize hosts from across the bumblebee phylogeny with very 
little cophylogenetic pattern (Williams, 2008). Typically, Psithyrus species parasitize just one host or a few host species of the same subgenus (review in: Alford 1975; Løken, 1984; Lhomme, 2009), but some species are considered to be generalists, with the extent of their host range often unclear. The ecology of host-parasite interactions of most of the cuckoo bumblebees is poorly known or unknown for almost half of Psithyrus.

This study focuses on two sister taxa, Bombus (Psithyrus) barbutellus (Kirby, 1802) and Bombus (Psithyrus) maxillosus Klug in Germar, 1817 of the former subgenus Allopsithyrus Popov, 1931, or barbutellus-group (Fig. 1) (i.e. Williams, 1998). The taxonomic status of these two taxa is doubtful (Grütte, 1940; Tkalců, 1969; Rasmont, 1988; Williams, 1998). Most authors consider these taxa as separate species (Popov, 1931; Pittioni, 1939; May, 1942, 1943; Tkalců, 1969; Løken, 1984) while very few argue for their conspecificity (Grütte, 1940). Most of these studies refer to morphology, highlighting slight differences between the two taxa (Table1), mainly from hair length and wing color (e.g. Tkalců, 1969). With such weak morphological criteria a large number of individuals remain unidentified (Rasmont, 1988; Rasmont \& Adamski, 1996; Urbanová et al., 2004) especially in geographical areas shared by both taxa. B. barbutellus has a large palaearctic distribution while $B$. maxillosus is restricted around the Mediterranean Sea (Fig. 1) (Rasmont, 1988; Pagliano, 1993; Rasmont \& Flagothier, 1996; Williams, 1998 update at NHM). Many overlapping areas and exceptions to these trends are known (Vogrin, 1955; Schwartz et al., 1996; Schwartz et al., 2005; Straka et al., 2007; Pawlikowski, 2008; Iserbyt, 2009). The splitting into subspecies differs for many authors (Pittioni, 1939; Grütte, 1940; Rasmont 1988). In this study, as a preliminary approach, we use the subspecies classification of Rasmont (1988): Bombus barbutellus no subspecies, $B$. maxillosus maxillosus Klug, 1817 (France, S-E Europe, Anatolia, Transcaucassia, Caucasus, and N Iran) and B. maxillosus italicus (Grütte, 1940) (Iberian Peninsulas, Italian Peninsulas, Corsica, and Sardinia). 


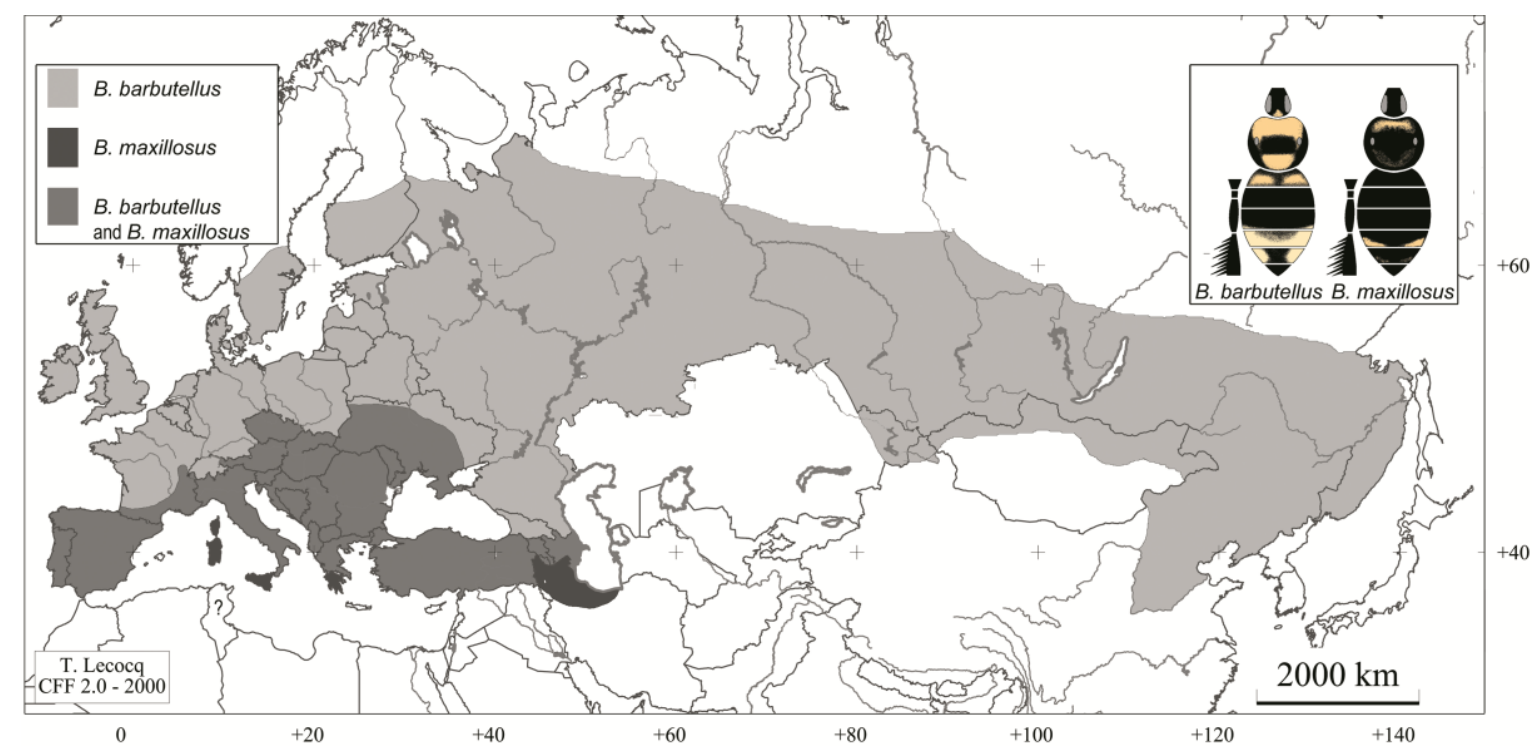

Fig. 1. Distribution area of Bombus maxillosus and Bombus barbutellus in the Palaeartic region according to the literature (Maidl, 1922; Pittioni, 1939; Haas, 1949, 1967; Vogrin, 1955; M'ocz'ar, 1957; Dylewska, 1966; Elfving, 1968; Reinig, 1971; Ressel, 1974; Alford, 1975; Tum`ss, 1975; Løken, 1984; Ornosa, 1984; Intoppa et al., 1995; Monsevicius, 1995; Rasmont et al., 1995; Amiet, 1996; Baker, 1996;

Rasmont \& Flagothier, 1996; Rasmont \& Adamski, 1996; Peeters et al., 1999; Dathe et al., 2001; Yefremova, 2001; Anagnostopoulos, 2005; Fitzpatrick et al., 2006; Byvaltsev, 2008, 2009; Pawlikowski, 2008; W. F. Reinig, personal data).

The sparsity of $B$. barbutellus and B. maxillosus makes information about their ecology very scarce. According to Pittioni \& Schmidt (1942) and Rasmont (1988), B. barbutellus and B. maxillosus have different habitats. B. barbutellus is a forest edge dweller. It is a plains species in the north of its range and a mountain species in the south. B. maxillosus seems to be more of an open field species (Pittioni \& Schmidt, 1942) or a wood edge species (Rasmont, 1988). They also seem to have different hosts. The main host of B. barbutellus is Bombus (Megabombus) hortorum (L., 1761) (Sladen, 1912; Ball, 1914; Müller, 1936; Cumber, 1949; Tkalců, 1969; Löken, 1984) whereas the main hosts of B. maxillosus seem to be two sisters species Bombus (Megabombus) argillaceus (Scopoli, 1805) and Bombus (Megabombus) ruderatus (Fabricius, 1793) (Reinig, 1935; Rasmont, 1988; Rasmont \& Adamski, 1996) close related to $B$. hortorum inside the Megabombus subgenus. However, other observations (Reinig, 1935; Pittioni \& Schmidt, 1942; May, 1943; Pouvreau, 1973; Ornosa, 1984; Rasmont \& Adamski, 1996; Westrich, 1989; Peeters et al., 1999) show that both taxa have no strict host-parasite relationship (Table 2). In this case, there is no definitive evidence to separate both taxa according to their host choice contrary to Tkalců's (1969) observations. 

have been described by Kullenberg et al. (1970) and Cederberg et al. (1984). The SMP of four specimens of B. maxillosus from Czech Republic have been described by Urbanová et al. (2004). These last authors compared their data with B. barbutellus of Kullenberg et al. (1970) and Cederberg et al. (1984). They found similarities in the blend of the SMP. However, due to the improvement in analysis techniques, data published before 1996 need to be re-examined (Terzo et al., 2003). Comparison between such old data and new data is difficult. Very few genetic studies including both taxa have been undertaken and none have dealt with species status. In recent estimates of bumblebee phylogeny, the two taxa are treated as different species (Cameron et al., 2007; Hines 2008).

Morphological, phylogenetic, ecological, and ethological data from literature about $B$. barbutellus and B. maxillosus are conflicting. A comparison of all available data fails to determine a strongly supported taxonomic hypothesis. We need more evidences in order to evaluate the status of both taxa (Williams, 1998 update at NHN). This paper aims to solve the taxonomic status of $B$. barbutellus and $B$. maxillosus using new molecular and chemical data from larger samples than previous studies.

\section{Material and Methods}

We compared morphological, molecular, and chemical (SMP) features from the same sampling of males (Table 3). Specimens were caught in the wild and killed by freezing. Identification keys which discriminate B. barbutellus and B. maxillosus as two species were used to determine individuals (Popov 1931; May 1943; Pittioni 1939; Rasmont \& Adamski, 1996). The SMP were sampled by dissection of cephalic labial glands which were placed in 
$200 \mu 1$ hexane (Terzo et al., 2005). The rest of the male bodies were conserved in ethanol (99\%) for molecular analyses. All samples were stored at $-40^{\circ} \mathrm{C}$ until analysis.

Scarcity of the species in the field restricts collection of a large quantity of specimens. We have analyzed 9 specimens of $B$. barbutellus, 10 of $B$. maxillosus maxillosus, and 3 of $B$. maxillosus italicus for pheromonal dataset. We added 4 specimens of B. barbutellus females to the molecular sampling. One male of B. maxillosus maxillosus from SMP sample was too deteriorated for DNA extraction. Sampled populations are mainly European, corresponding to the sympatric area of the two taxa (Table3; Fig.1).

In order to root phylogenetic trees, we choose basal Psithyrus species and one other bumblebee species as outgroup. We used Bombus (Psithyrus) campestris (Panzer, 1801) from the Metapsithyrus group (Pedersen, 1996; Pedersen, 2002; Cameron et al., 2007), Bombus (Psithyrus) rupestris (Fabricius, 1793) from the Psithyrus s.s. group (Cameron et al., 2007; Hines, 2008) and Bombus (Kallobombus) soroeensis (Fabricius 1777) as outgroup (Table 3).

\section{DNA extraction, PCR, sequencing and sequence analyses}

Total DNA was extracted using a QIAGEN DNeasy ${ }^{\circledR}$ Tissue Kit (Quiagen Inc., Valencia, CA). Legs were removed from the specimen and crushed using liquid nitrogen and digested ( $4 \mathrm{~h}$ in proteinase $\mathrm{K}$ at $56^{\circ} \mathrm{C}$ ). Voucher specimens and PCR products used in the molecular investigation were deposited at the University of Mons (Belgium). Genes were sequenced with ABI 3730XL sequencer (Applied Biosystems, Foster City, CA, USA). Both strands of each PCR product were sequenced. Consensus sequences were computed with CodonCode Aligner 3.0.1. (Table 3). The bumblebee origin of each sequence was checked with BLAST 2.2.20 (Zhang et al., 2000). The alignment was performed by MAFFT ver.6. (using FFT-NS-2 algorithms, default parameters) (Katoh et al., 2002). The translation in proteins (using the drosophila mt DNA genetic code) for verification and the data matrix was realized on 
Mesquite 2.6. (build 486) (Maddison \& Maddison, 2007). Sequences were deposited in Genbank (Table 3).

We generated sequences for two genes: Mitochondrial Cytochrome Oxidase 1 (COI) and nuclear protein-encoding gene Elongation Factor-1 alpha $(\mathrm{EF}-1 \alpha)$. COI show a high mutation rate and it is commonly used as a species and subspecies level marker for phylogenetic analyses (e.g. Boursot \& Bonhomme, 1986; Estoup et al., 1996; Danforth, 1999; Koulianos \& Schmid-Hempel, 2000). EF-1 $\alpha$ has been used to infer relationships at multiple taxonomic levels in many insect taxa including bumblebees (Danforth, 1999; Carapelli, 2000; Kjer, 2001; Jordal, 2002; Cameron et al., 2007; Hines, 2008). Both genes have already been used to infer the phylogenetic relationship among European bumblebees (Pedersen, 2002). Primers used for all individuals were Jerry (5'-CCA CAT TTA TTT TGA TTT TTT GG-3') and Pat (5'-TCC AAT GCA CTA ATC TGC CAT ATT A-3') (Danforth 1999) for COI and F2-ForH (5'-GGR CAY AGA GAT TTC ATC AAG AAC-3') and F2-RevH2 (5'-TTG CAA AGC TTC RKG ATG CAT TT-3') (Hines et al., 2006) for EF-1 $\alpha$. PCR amplification was carried out (initial denaturing for $4 \mathrm{~min}$ at $94^{\circ} \mathrm{C}, 35$ cycles of $1 \mathrm{~min}$ denaturing at $94^{\circ} \mathrm{C}, 1 \mathrm{~min}$ annealing at $54^{\circ} \mathrm{C}(\mathrm{EF}-1 \alpha)-51^{\circ} \mathrm{C}(\mathrm{COI}), 1 \mathrm{~min}$ elongation at $72^{\circ} \mathrm{C}$ and a final extension for $1 \min 15 \sec (\mathrm{EF}-1 \alpha)-1 \mathrm{~min} 30 \sec (\mathrm{COI})$ at $\left.72^{\circ} \mathrm{C}\right)$. Gene fragments of the following sizes were amplified: 849 nucleotides of COI and 786 nucleotides of EF-1 $\alpha$ F2 copy, containing a 200 bp intron.

\section{Phylogenetic analyses}

We analyzed each gene (COI and EF-1 $\alpha$ ) independently and in combination using Maximum Parsimony (MP), Maximum Likelihood (ML) and Bayesian Methods (MB). A test of saturation was applied to each fragment in PAUP* 4.0b 10 (Swofford, 2001). The Incongruence Length Difference test (ILD test) (Farris et al., 1994) was used to test for incongruence between the two genes. The test was implemented in PAUP* (Swofford, 2001). 
All trees were rooted with the basal taxon B. soroeensis (Williams, 1985; Cameron et al., 2007).

Heuristic searches were performed in MP using 1000 random additions and TBR branch swapping, keeping the best trees only. Gaps were regarded as 5th state. Majority rule 50\% consensus (MJ50) trees were constructed from analyses of individual genes and from all genes combined using parsimony criteria in Paup* 4.0b 10 (Swofford, 2001) for equallyweighted MP analyses. Clades support values were estimated using nonparametric bootstrapping (Felsentein, 1985) in PAUP* (10000 replicates, 1000 random additions, 500 trees saved per replicate).

ML analyses were conducted in GARLI-PART Version 0.97 (Zwickl, 2006). The dataset was partitioned as followed to explore the best submission model: (1) EF-1 $\alpha$ into two exons and one intron, (2) COI and each EF-1 $\alpha$ exon by base position. The best fitting substitution models were chosen with jModeltest (Posada, 2008) using Akaike information criteria (Akaike 1974) for each dataset. The models chosen are: GTR $+\mathrm{G}$ (COI $1^{\text {st }}$ position), GTR (COI $2^{\text {nd }}$ position), GTR $+\mathrm{I}+\mathrm{G}\left(\mathrm{COI} 3^{\text {rd }}\right.$ position), F81 (EF-1 $\alpha$ exon $11^{\text {st }}$ position), F81 (EF-1 $\alpha$ exon $12^{\text {nd }}$ position), HKY (EF-1 $\alpha$ exon $13^{\text {rd }}$ position), GTR+G (EF-1 $\alpha$ intron), HKY (EF-1 $\alpha$ exon $21^{\text {st }}$ position), JC (EF-1 $\alpha$ exon $22^{\text {nd }}$ position) and GTR+G (EF-1 $\alpha$ exon $23^{\text {rd }}$ position). A random starting tree and the automated stopping criteria (stop when the ln score remained constant for 20000 consecutive generations) were used. Ten independent runs in GARLI were carried out for each gene and for the combined data; the topology and - $\ln \mathrm{L}$ were nearly identical among replicates. The highest likelihood of those runs was retained. Statistical confidence in nodes was evaluated using 100 non-parametric bootstrap replicates (Felsentein, 1985) using the automated stopping criteria set at 10000 generations. More bootstrap replicates could not be performed because it would have required unpractical computing 
times. Topology with $\geq 70 \%$ of the bootstrap trees were considered well supported (Hillis $\&$ Bull, 1993).
Bayesian analyses (MB) were carried out using Mr. Bayes 3.1.2 (Ronquist \& Huelsenbeeck, 2003). The model selection process was the same as that for ML analysis. Moreover, genes were analyzed individually and collectively. Five independent analyses were carried out for each gene and for the combined data (10 millions generations, four chains with mixed-models, default priors, saving trees every 100 generations). The analyses were stopped after checking convergence between runs using the average standard deviation of split frequencies and by plotting likelihood values across generations using Tracer 1.2 (Rambaut \& Drummond, 2003). The first one million generations were discarded as burn-in. The phylogeny and posterior probabilities were then estimated from the remaining trees and a majority-rule $50 \%$ consensus tree was constructed. Topologies with posterior probabilities $\geq$ 0.95 were considered well supported (Wilcox et al., 2002).

\section{Chemical Analyses}

The samples were analyzed using a gas chromatograph Shimadzu GC-2010 with a SLB5ms non-polar capillary column (5\% diphenyl/95\% dimethyl siloxane; $30 \mathrm{~m} \mathrm{X} 0.25 \mathrm{~mm} \mathrm{X}$ $0.25 \mu \mathrm{m})$ and a flame ionization detector. A split less injector mode $\left(220^{\circ} \mathrm{C}\right)$ and $\mathrm{He}$ carrier gas $(50 \mathrm{~cm} / \mathrm{s})$ were used. The temperature program of the column was $70^{\circ} \mathrm{C}$ for $2 \mathrm{~min}$; $10^{\circ} \mathrm{C} / \mathrm{min}$ to $320^{\circ} \mathrm{C} ; 5 \mathrm{~min}$. Relative proportions in percentage of each compound were calculated by summing up the absolute amounts of all compounds using GCsolution Postrun. The data matrix was elaborated with the relative proportion of each compound for each individual. The composition of SMP was determined using a gas chromatograph - mass spectrometer (GC-MS) Finigan GCQ with a DB-5ms non-polar capillary column (5\% phenyl (methyl) polysiloxane stationary phase; $30 \mathrm{~m} \mathrm{X} 0.25 \mathrm{~mm} \mathrm{X} 0.25 \mathrm{~mm}$ ) and an ion trap in electron impact mode "full scan (300-600)". A split less injector mode $\left(220^{\circ} \mathrm{C}\right)$ and He carrier 
gas $(50 \mathrm{~cm} / \mathrm{s})$ were used. The temperature program of the column was $70^{\circ} \mathrm{C}$ for $2 \mathrm{~min}$; $10^{\circ} \mathrm{C} / \min$ to $320^{\circ} \mathrm{C} ; 5 \mathrm{~min}$. Compounds were identified in Xcalibur ${ }^{\mathrm{TM}}$ using their mass spectra compared to those at National Institute of Standards and Technology library (NIST, U.S.A) using Nist MS Search 2.0.

Statistical analyses were performed in R (Quinn \& Keough, 2006). Data were transformed and standardized. Clustering methods were used to detect divergence between taxa (Rasmont et al., 2005). Four different association matrixes based on pheromonal data matrix (relative abundance of each compound) were computed: Euclidian, Pearson Phi Correlation, ChiSquare, and Manhattan. Three clustering methods were used for each association matrix: single, complete and UPGMA. Only one of these clusters is shown in the results (UPGMA cluster based on Phi Correlation matrix). In addition, a 2-group k-means method (MacQueen, 1967) was performed (repeated 50.000 times) (De Meulemeester et al., 2011) to test a putative split into two groups: B. barbutellus versus B. maxillosus.

\section{Correlation analyses}

The spatial structuring of the chemical and genetic data set and a potential correlation between these two data sets were investigated by performing three Mantel tests (9999 random permutations) (Mantel, 1967) in R (Quinn \& Keough, 2006): (1) geographical distance among population versus individual by individual correlation distance in relative amounts of SMP compounds, (2) geographical distance versus individual by individual genetic distance and (3) correlation distance of the SMP versus Genetic distance. The correlation distance matrix of SMP compounds was performed in R (Quinn \& Keough, 2006). Genetic distances were calculated in Mega 4.0.1 (Tamura et al., 2007) using the maximum composite likelihood (MCL). The MCL calculations used data for both transitions and transversions and assumed a heterogeneous pattern of sequence evolution with a gamma distribution of among-site rate variation $($ gamma parameter $=1.0)$. Gaps, missing data and individuals without all data set 
were deleted from the analysis and standard errors were calculated with 1000 bootstrap replicates.

\section{Results}

Phylogenetic analyses

A total of $850 \mathrm{bp}$ from the COI gene (145 parsimony informative sites), 773 nucleotides of EF-1 $\alpha$ F2 copy (24 parsimony informative sites), containing a $~ 200$ bp intron and the combined sequences were compared to estimate the phylogenetic relationships. All analyses (MP, ML and MB) on each single gene and combined dataset present the same topology (Figs $2,3,4)$ but higher branch support values were found in MB. Phylogenetic analyses based on EF-1 $\alpha$ partially recover all deep relationships among Psithyrus subgroups but failed to provide much sequence variation within and between B. barbutellus and B. maxillosus. Moreover there is not any divergence between B. barbutellus and B. maxillosus while a clear divergence appeared in the Ashtonipsithyrus species group (B. bohemicus and B. vestalis). COI tree topology failed to resolve deep relationships among Psithyrus subgroups but provided considerable sequence variation of B. barbutellus and B. maxillosus. As in the EF-1 $\alpha$ analyses, B. barbutellus and B. maxillosus were not split into two groups. Nevertheless geographic groups appeared: A West-Central European group, a Southern French group, two Turkish groups and a Corsican group (Fig. 3). However branch support values are low in posterior probability but well supported in ML and MP. Combined genes analyses summarize the differing contributions of the two molecules at the two ends of the tree. These trees presented a similar topology and similar branch supports to EF-1 $\alpha$ for deep relationship between Psithyrus subgroups and to COI for the tips of the phylogeny (including COI geographic groups). In each of the analyses, therefore, there was an unambiguous support for monophyly of the B. barbutellus + B. maxillosus group. 


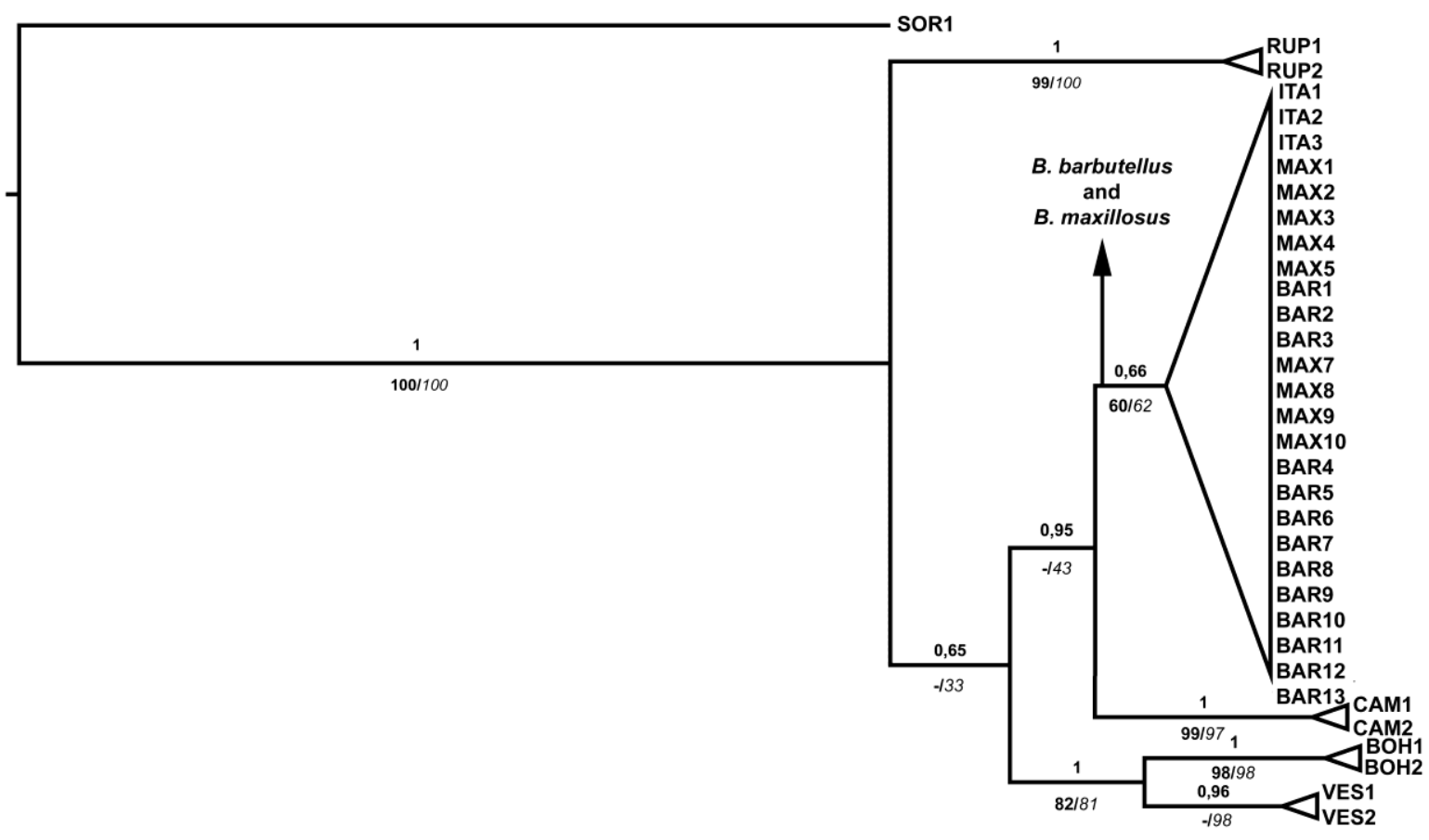

Fig. 2. Majority-rule (50\%) consensus tree based on Bayesian analyses of elongation factor $1 \alpha(E F-1 \alpha)$ sequences; values above branches are Bayesian posterior probabilities; values in bold below branches are maximum likelihood bootstrap values; values in italic below branches are maximum parsimony bootstrap values. Bombus soroeensis is used as the out-group. The triangles represent clades with shared haplotypes. The sample codes are defined in Table 3.

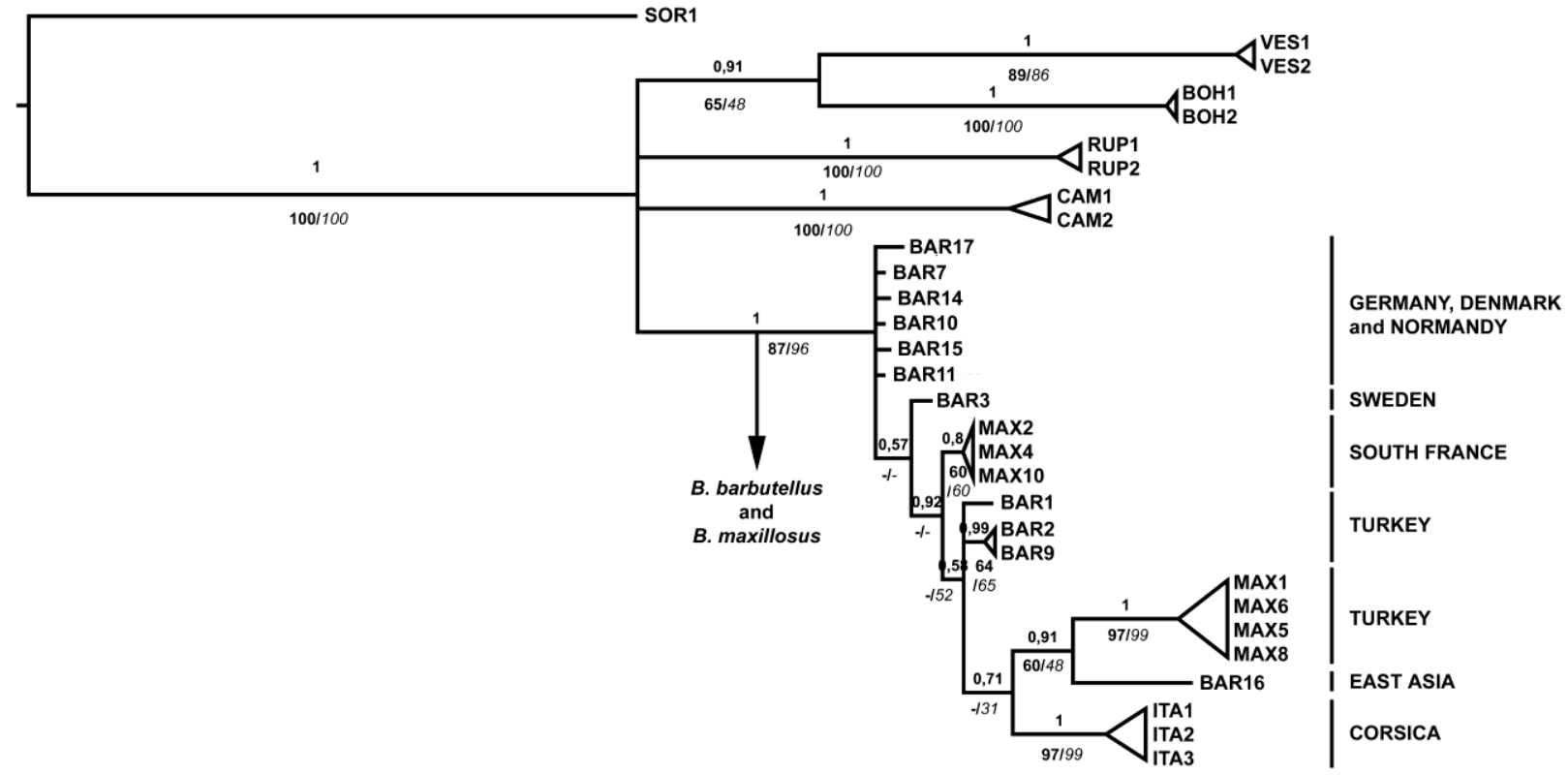

Fig. 3. Majority rule (50\%) consensus tree based on Bayesian analyses of cytochrome $c$ oxidase subunit I (COI) sequences; values above branches are Bayesian posterior probabilities; values in bold below branches are maximum likelihood bootstrap values; values in italics below branches are maximum parsimony bootstrap values. Bombus soroeensis is used as the out-group. The triangles represent clades with shared haplotypes. The sample codes are defined in Table 3. 


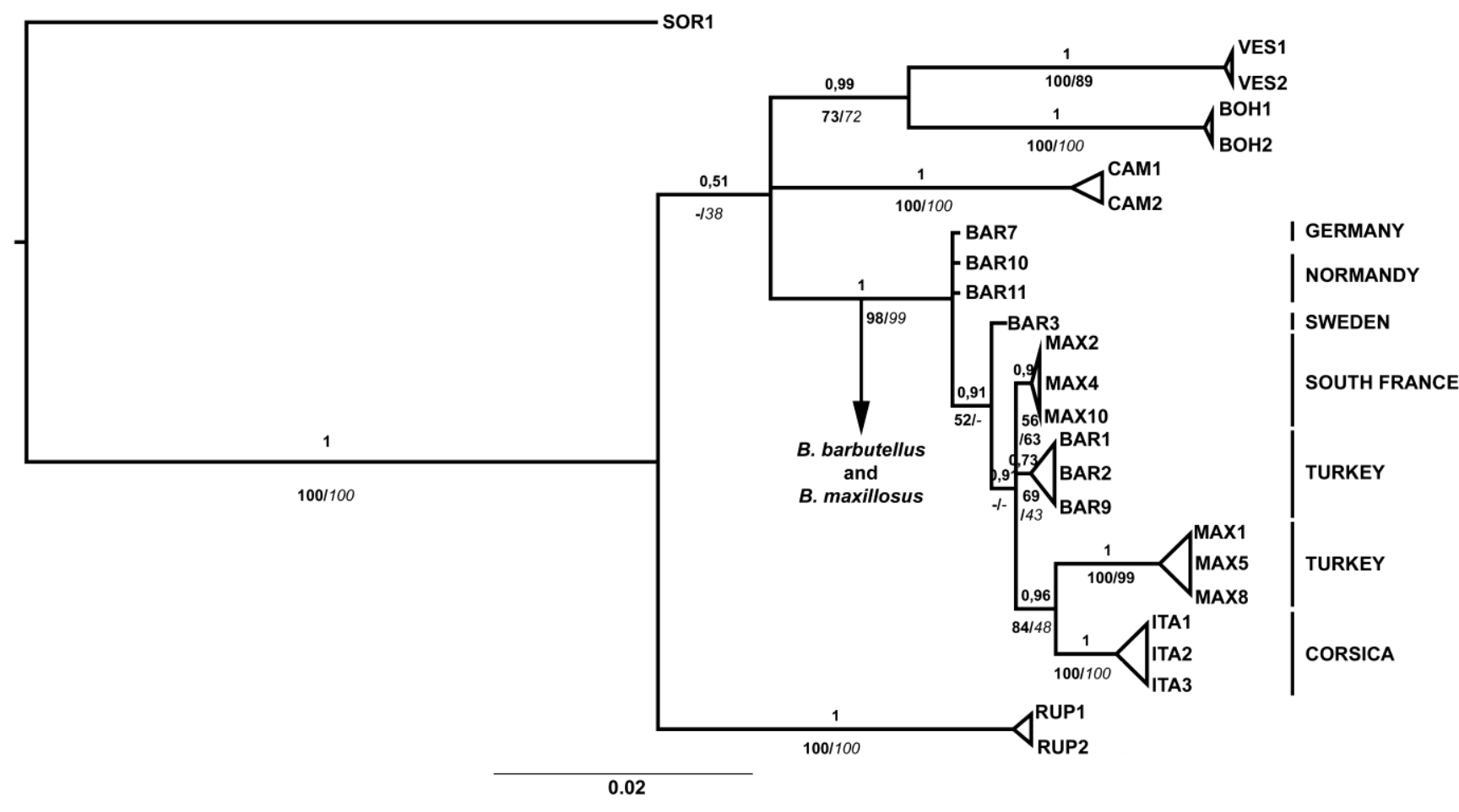

Fig. 4. Majority rule (50\%) consensus tree based on Bayesian analyses of the combined molecular data matrix ( $E F$ - $1 \alpha$ and $C O I$ ); values above branches are Bayesian posterior probabilities; values in bold below branches are maximum likelihood bootstrap values; values in italic below branches are maximum parsimony bootstrap values. Bombus soroeensis is used as the out-group. The triangles represent clades with shared haplotypes. The sample codes are defined in Table 3.

\section{Chemical analyses}

73 compounds were detected in SMP of B. barbutellus and B. maxillosus (Table 4). B. barbutellus and $B$. maxillosus shared all compounds. No discrimination between $B$. barbutellus and B. maxillosus was found in the statistical analyses (Figs 5, 6). PCA analysis did not separate any group. However, all the clusters separated the samples into two main groups; a Turkey cluster with nearly all the Turkish individuals and a European cluster with all European samples and one Turkish specimen (Fig. 6). The two group k-means method detected the same separation. Only slight quantitative and qualitative divergences in the minor compounds separated the two groups. Examination of the wing condition (Tkalců, 1969) of the Turkish individual grouped with the European group indicated that it is obviously an old specimen. In some bumblebee species, old individuals, scarce in the wild, have a pheromonal composition modification and are probably no longer attractive to females (Žaček et al., 2009; 

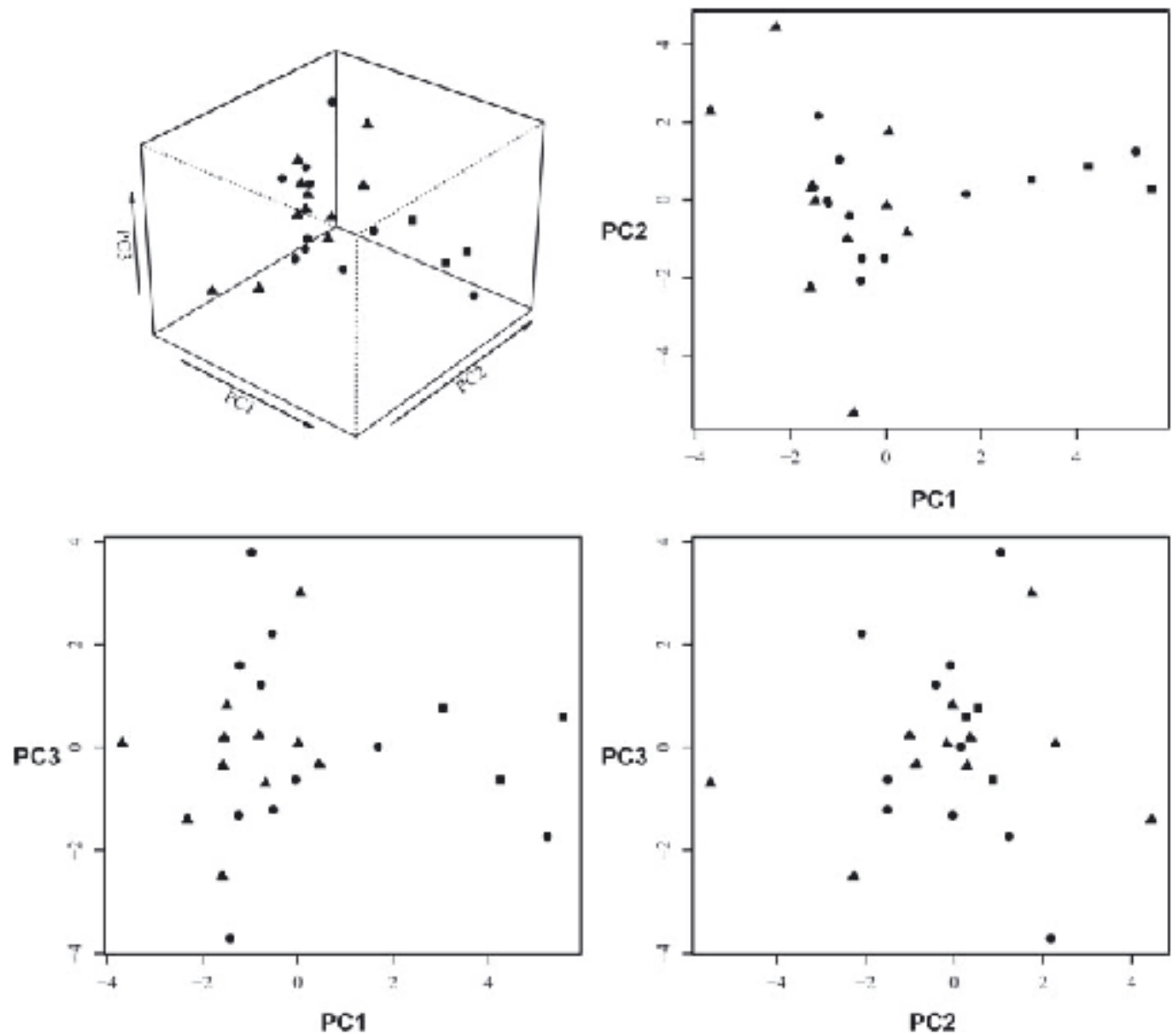

Fig. 5. Three first axes of the principle components analysis (PCA) based on 20 compounds in 21 specimens of Bombus barbutellus, Bombus maxillosus maxillosus and Bombus maxillosus italicus; , Bombus barbutellus; , Bombus maxillosus italicus; , Bombus maxillosus maxillosus. 


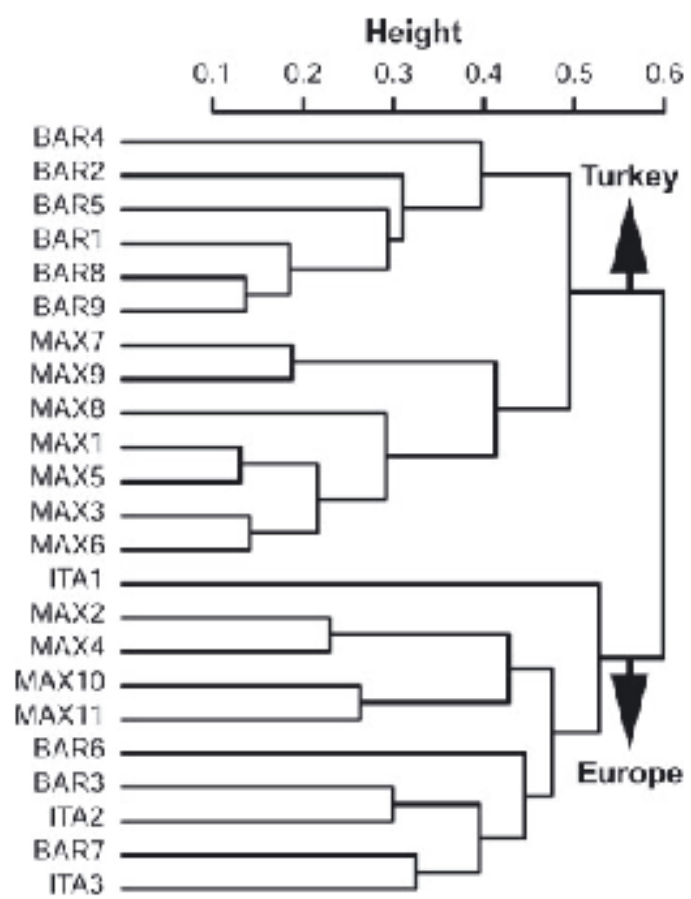

Fig. 6. Unweighted pair group method with arithmetic mean (UPGMA) cluster based on a correlation matrix calculated from the sexual marking pheromone (SMP) matrix of Bombus barbutellus, Bombus maxillosus maxillosus and Bombus maxillosus italicus (73 compounds in 21 specimens). The sample codes are defined in Table 3.

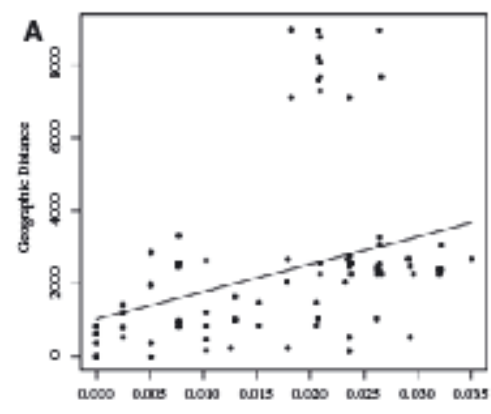

cenede Dimax
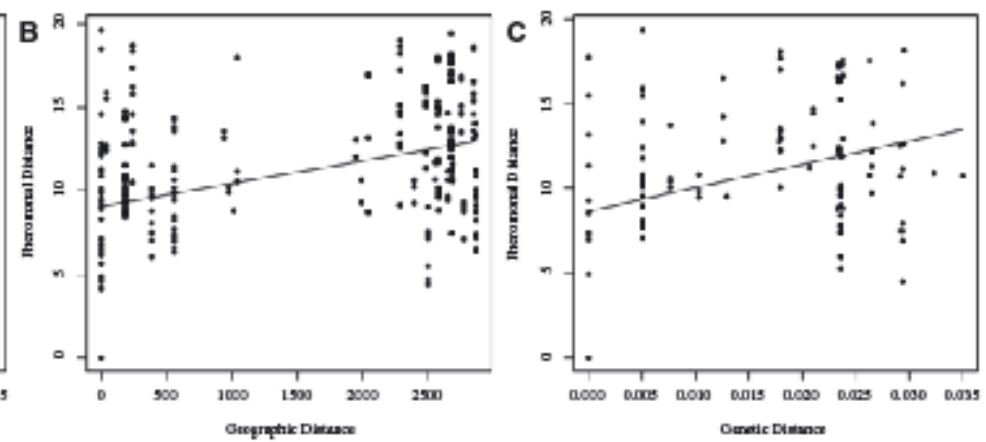

Fig. 7. Mantel's correlogram of (A) genetic distance among genetic samples plotted by spatial distance among samples sites (Mantel's $r=$ 0.293; $P<0.05)$; (B) correlation distance among chemical samples plotted by spatial distance among samples sites $($ Mantel's $r=0.298 ; P<$ 0.05); (C) genetic distance among genetic samples plotted by correlation distance among chemical samples (Mantel's $r=0.089 ; P>0.05)$.

\section{Correlation analyses}

The Mantel tests show a significant positive correlation between SMP dissimilarity and geographical distance (Mantel's $r=0.298$, $\mathrm{p}$-value $<0.05$ ) and between genetic distance and geographical distance (Mantel's r=0.293; p-value<0.05) (Figs 7A, B). There is no correlation between SMP dissimilarity and genetic distance (Mantel's r=0.089; p-value>0.05) (Fig. 7C).

\section{Discussion}

\section{Species status}


The phylogenetic trees showed conflict with Cameron et al. (2007) and Hines (2008).

Though these studies were not designed to deal with species problems, they showed genetic differences in EF-1 $\alpha$ sequence between B. barbutellus and B. maxillosus. However, these studies used only one Swedish B. barbutellus specimen and one Turkish B. maxillosus specimen. By performing a wider specimen sampling taking into consideration the intraspecific variability, we show that B. barbutellus or B. maxillosus respectively do not constitute monophyletic groups. Therefore they are not different species according to the Phylogenetic Species Concept (Baum, 1992).

Our results in SMP composition are similar to Urbanová et al. (2004). 58 compounds detected in GC-MS analysis were identical to the former study; 15 components with a relative abundance below $0.1 \%$ and four components with a relative abundance higher than $0.1 \%$ differed. Among these compounds only three were present in all individuals. However the differences observed with Urbanová et al. (2004) are of the same order of magnitude as the inter-population variation observed in our data set for B. barbutellus. Pheromonal analyses also support a lack of divergence between B. barbutellus and B. maxillosus. The comparison of SMP between the two taxa showed only some slight quantitative modifications and no qualitative modifications and supports their conspecificity according to the species recognition concept (Paterson, 1993). Indeed, the variation observed between B. barbutellus and B. maxillosus is lower than the intraspecific variation observed in Bombus terrestris (Coppée et al., 2008) and even more so the variation between other bumblebees species (Bertch, 1997; Bertsch et al., 2005; Rasmont et al., 2005; Terzo et al., 2005).

Our chemical and molecular analyses point towards conspecific status for B. barbutellus and $B$. maxillosus whatever the species concept considered. Moreover, these analyses do not support any separation of alternative species inside the B. barbutellus + maxillosus group. This result agrees with Grütte (1940). The taxonomic status proposed by Grütte (1940) was 
criticized by Tkalců (1969) according to wing darkness variations and host choice. Tkalců (1969) considered wing darkness of all bees as a constant specific criterion unrelated to individual or geographic variations. However, according to our results, wing darkness is not a diagnostic species character of $B$. barbutellus. The relevance of the wing darkness as a species diagnostic character among bees, never demonstrated statistically from a large sample, therefore still needs to be proven. To summarize, according to the conspecificity shown in our results, the main morphological criteria (the hair length and the wings darkness) used to distinguish both taxa (Popov, 1931; Pittioni, 1939; May, 1942; May, 1943) is probably due to intraspecific variability. This could explain the numerous intermediate forms observed by Grütte (1940) and the large number of undeterminable individuals (Rasmont, 1988).

\section{Intraspecific variability}

We found three colour patterns corresponding to the following subspecies (sensus Rasmont, 1988): barbutellus, italicus, and maxillosus. However colour patterns do not fit with any particular pheromonal clustering or phylogenetic tree. This could show that there is no clear subspecific subdivision with the Rasmont (1988) subspecies status but only two extreme forms: (1) a form with long hairs and hyaline wings (barbutellus) living in the North of Europe and in the Mediterranean mountains; (2) another form with short darker hairs and darkened wings (maxillosus) living mainly in the South of Europe and (3) between these two, there are intermediate forms; sometimes described as subspecies (Grütte, 1940). Similar patterns of variations have been observed in other bumblebees. On the one hand, hairs insulate the bumblebee bodies and decrease heat loss (Heinrich, 1975). Peat et al. (2005) showed that bumblebee species from hot regions exhibit shorter hairs than species from cold regions. They found the same geographic pattern at an intraspecific level for B. terrestris. On the other hand, melanism is also due to thermoregulation (Gloger, 1833). Hot region bumblebees are darker and temperate region bumblebees are paler (Williams, 2007). In 
Scandinavia, Løken (1984) observed a slight tendency to a more pronounced melanism in the south of Sweden than in the north among B. barbutellus.

The genetic distance observed in B. barbutellus is correlated to geographic distances according to our Mantel test like amongst other bumblebees (Estoup et al., 1996; Widmer et al., 1998). However, any groups inside the barbutellus phylogenetic tree match with any distinct coloration group. It could support population variations but not a clear subspecific taxonomy.

The slight SMP geographic variations mainly between Turkey and Europe are explained by the geographic distance. Mantel test shows that SMP distance is correlated to geographic distance like in other bees (Vereecken et al., 2007; Coppée et al., 2008; Lecocq et al., 2009b). Among the Turkish group, the splitting into two forms (barbutellus forms and maxillosus forms) may be due to an interpopulational variation as observed in $B$. terrestris (Coppée 2010) or more likely reflects sampling bias. Indeed, Turkish B. barbutellus samples were collected at the same time and from the same place. The likelihood that these individuals were related and thus have a nearly identical SMP composition is high. In this case, the clustering method separated them from other samples with no other biological reason than the kin relationship.

Even if we observed variations between $B$. barbutellus populations, currently, we do not know if these variations have an impact on the intraspecific sexual mating recognition among B. barbutellus. Ethological studies, difficult to perform among scarce species, would resolve this problem.

Moreover, phylogenetic and pheromonal geographic groups never match in our analysis and are not correlated according to the Mantel test. Therefore, we are unable to discover any subspecies differentiation.

\section{Host relationship}


As a consequence of our present taxonomic definition, B. barbutellus seems to be an opportunistic cuckoo bumblebee with preferences for host species belonging to the subgenus Megabombus. The differences in the main host choice of the form barbutellus (B. hortorum) and the form maxillosus (B. argillaceus and B. ruderatus) do not reflect a species differentiation. The definition of the species status in inquiline bumblebees should not be based on host choice differences. Indeed, in few cases where information is available (review in Williams, 2008) bumblebee socially parasitic lineages tend not to be strict specialists, several Psithyrus species are known to parasitize multiple species in their communities

\section{Impact on zoological nomenclature}

Bombus barbutellus (Kirby) is the only species belonging to the group formerly known as the subgenus Allopsithyrus Popov. Bombus maxillosus should be regarded as a simple synonym. The oldest available names for the species are the following:

? Apis brachyptera Villers in L., 1789: 331, nomen oblitum

? Apis monarcha Christ, 1791: 131, nomen oblitum

? Apis cincta Preyssler, 1793: 232, nec Fabricius, 1781, nomen oblitum

? Apis saltuum Panzer, 1800-1801, part 75, Table21, nomen oblitum.

Apis barbutella Kirby, 1802: 343, nomen protectum; locus typicus: England E.Suffolk Barham; lectotype $\subsetneq$ Natural History Museum, London, designated by Yarrow, 1968. Revised by P. Rasmont 2010. Labels 1) handwritten "93"; 2) round blue pale label with glued right protarsus; 3) round with a black circle printed "Lectotype"; 4) handwritten "Apis barbutella Kirby 1802 LECTOTYPE I.H.H. Yarrow 1968; 5) printed and handwritten "B.M. TYPE HYM 17a 2996". The right fore tarsis is broken and glued to the second label. The 3 distal segments of the hind tarsus are missing. The coat colour pattern is typical to the northern form of Bombus barbutellus, but the wings are more infuscated than usual. 

Museum, Berlin, see Tkalců, 1969. Syn. N.

465

466

The oldest names, Apis brachyptera Villers, Apis monarcha Christ, Apis cincta Preyssler and Apis saltuum Panzer have a description that does not allow us to identify the taxa with certainty, while no types are presently known. These names have not been used since their initial description. They are therefore all nomina oblita.

The oldest available name is Apis barbutellus Kirby; Bombus maxillosus Klug is therefore a subjective junior synonym. The valid name should be Bombus (Psithyrus) barbutellus (Kirby, 1802). Many names have been used for infraspecific colour forms, mainly by Kriechbaumer (1870), Popov (1931), Quilis-Pérez (1927), Müller (1936), Pittioni (1939) and May (1944). They are all considered here as synonyms of Bombus barbutellus (Kirby).

\section{Acknowledgments}

We are very grateful to B. N. Danforth and M. M. López-Uribe for the hosting in Cornell University (Ithaca, U.S.A.) and to P. Mardulyn for the hosting in the ULB (Bruxelles, Belgium) for the molecular analysis. We gratefully acknowledge M. Terzo (Mons, Belgium), A. Roelandts (Mons, Belgium), E. Stolle (Halle, Germany), and G. Mahé (Saint-Nazaire, France) for providing Psithyrus samples. Thanks also to P. H. Williams (London, United Kingdom) for help and comment on the taxonomic nomenclature. We are also grateful to T. De Meulemeester (Mons, Belgium) for statistical analysis. The authors acknowledge the Fonds pour la recherche dans l'industrie et l'agriculture (FRIA), Fonds pour la Formation à la Recherche Fondamentale et Collective (FNRS), the Office de l'Environnement de la Corse, the Direction Régionale de l'Environnement de Corse for the financial support. Special thanks are also due to Dr. A. Coppée (Mons, Belgium), Prof. A. M. Aytekin (Ankara, Turkey), Dr. S. Patiny (Gembloux, Belgium), Dr. D. Lanterberq (Mons, Belgium) and S. Lambert for helpful 
487 comments and discussions on earlier versions of this manuscript and B. Lhomme for the 488 English. 
Akaike, H. (1974) A New Look at the Statistical Model Identification. IEEE Transactions on Automatic Control, 19, 716-723.

Alford, D. V. (1975) Bumblebees. London.

Amiet, F. (1996) Hymenoptera Apidae, 1. Teil. Allgemeiner Teil, Gattungsschlüssel, die Gattungen Apis, Bombus und Psithyrus. Insecta Helvetica (Fauna), 12, 98 pp.

Anagnostopoulos, I. T. (2005) The bumblebee fauna of Greece: An annotated species list including new records for Greece (Hymenoptera: Apidae, Bombini). Linzer biol. Beitr., 37, 1013-1026.

Avise, J. (2000) Phylogeography: the history and formation of Species. Harvard University Press, Cambrdge, MA. 447 pp.

Aytekin, A. M., Terzo, M., Rasmont, P. \& Cagatay, N (2007) Landmark based geometric morphometric analysis of wing shape in Sibiricobombus Vogt (Hymenoptera : Apidae : Bombus Latreille). Annales De La Societe Entomologique De France (n.s.), 43, 95-102.

Baker, D. B. (1996) On a collection of humble-bees from northern Iran (Hymenoptera: Apoidea, Bombinae). Beiträge zur Entomologie, 46, 109-132.

Ball, F. J. (1914) Les bourdons de la Belgique. Annales de la Société entomologique de Belgique, 58, 77-108.

Batalha-Filho, H., Waldschmidt, A., Campos, L. A. O., Tavares, M. G. \& Fernandes-Salomão, T. (2010) Phylogeography and historical demography of the Neotropical stingless bee Melipona quadrifasciata (Hymenoptera, Apidae): incongruence between morphology and mitochondrial DNA. Apidologie, 614.

Bauer, A.M., Parham, J.F., Brown, R.M., Stuart, B.L., Grismer, L., Papenfuss, T.J., Böhme, W., Savage, J.M., Carranza, S., Grismer, J.L., Wagner, P., Schmitz, A., Ananjeva, N.B. \& Inger, R.F. (2010) Availability of new Bayesian-delimited gecko names and the importance of character-based species descriptions. Procceding of the royal society $B$, (doi: 10.1098/rspb.2010.1330)

Baum, D. (1992) Phylogenetic species concepts. Trends in Ecology and Evolution, 7, 1-3.

Baum, D. A. \& Shaw, K. L. (1995) Genealogical perspectives on the species problem. In Experimental and molecular approaches to plant biosystematics (ed. P. C. Hoch), pp. 289-303. St. Louis, MI: Missouri Botanical Garden.

Bergman, P. (1997) Chemical communication in bumblebee premating behaviour. $\mathrm{Ph}-\mathrm{D}$ thesis. Göteborg University. Göteborg.

Bergström, G., Svensson, B. G., Appelgren, M. \& Groth, I. (1981) Complexity of bumble bee marking pheromones: biochemical, ecological and systematical interpretations. Systematics Association special volume, 19, 175-183.

Bernasconi, C., Pamilo, P. \& Cherix, D. (2010) Molecular markers allow sibling species identification in red wood ants (Formica rufa group). Systematic Entomology, 35, 243-249.

Bertsch, A. (1997) Wieviele Arten der Untergattung Terrestribombus (Hymenoptera, Apidae) gibt es in Nordhessen; die Abgrenzung von Bombus cryptarum und B. lucorum mittels männlicher Labialdrüsen-
Sekrete und morphologischer Merkmale. Marbuger Entomologische Publikationen, 2, 1-28.

Bertsch, A., Schweer, H., Titze, A. \& Tanaka, H. (2005) Male labial gland secretions and mitochondrial DNA markers support species status of Bombus cryptarum and B. magnus (Hymenoptera, Apidae). Insectes Sociaux, 52, 45-54.

Bickford, D., Lohman, D. J., Sodhi, N. S., Ng, P. K. L., Meier, R., Winker, K., Ingram, K. K., Das, I. (2007) Cryptic species as a window on diversity and conservation. Trends in ecology and evolution, 22, 3, 148-155.

Bolton, B. (1995) A new general catalogue of the ants of the world. Havard University Press, Cambrdge, MA. $504 \mathrm{pp}$.

Boursot, P. \& Bonhomme, F. (1986) Génétique et évolution du génome mitochondrial des Métazoaires. Versailles, France.

Burns, J., M., Janzen, D. H., Hajibabaei, M., Hallwachs, W. \& Hebert, P. D. (2008) DNA barcode and cryptic species of skipper butterflies in the genus Perichares in Area de Conservación Guanacaste, Costa Rica. Proceeding of the National Academy of Sciences of the United States of America, 105 (17), 6350-6355.

Byvaltsev, A. M. (2008) Bumblebee (Hymenoptera : Apidae, Bombini) fauna of the forest steppes and steppe zones of the West Siberian Pain. Eurasian entomological journal, 7, 141-147.

Byvaltsev, A. M. (2009) The community of Bumble Bees (Hymenoptera : Apidae, Bombini) in the city of Novosibirsk and its environs. Contemporary Problems of Ecology, 2, 216-223.

Calam, D. H. (1969) Species and sex-specific compounds from the head of male bumblebees (Bombus spp). Nature, 21, 856-857.

Cameron, S. A., Hines, H. M. \& Williams, P. H. (2007) A comprehensive phylogeny of the bumble bees (Bombus). Biological Journal of the Linnean Society, 91, 161-188.

Carapelli, A., Frati, F., Nardi, F., Dallai, R. \& Simon, C. (2000) Molecular phylogeny of the apterygotan insects based on nuclear and mitochondrial genes. Pedobiologia, 44, 361-373.

Cederberg, B., Svensson, B. G., Bergström, G., Appelgren, M. \& Groth, I. (1984) Male Marking Pheromones in the North European Cuckoo Bumble Bees, Psithyrus (Hymenoptera, Apidae). Nova Acta Regiae Societatis Scientiarum Upsaliensis., 3, 161166.

Coppée, A. (2010) Bombus terrestris : a complex species or a species complexe. Université de Mons. Mons (Belgium).

Coppée, A., Terzo, M., Valterová, I. \& Rasmont, P. (2008) Intraspecific Variation of the Cephalic Labial Gland Secretions in Bombus terrestris (L.) (Hymenoptera: Apidae). Chemistry \& Biodiversity, 5, 2654-2661.

Cumber, R. A. (1949) The biology of the humble-bees, with special reference to the production of the worker caste. Transactions of the Royal Entomological Society of London, 100, 1-45.

Danforth, B. N. (1999) Phylogeny of the bee genus Lasioglossum (Hymenoptera: Halictidae) based on mitochondrial COI sequence data. Systematic 
Entomology, 24, 377-393.

Dathe, H. H., Taeger, A. \& Blank, S. M. (2001) Verzeichnis der Hautflügler Deutschlands (Fauna Germanica 4). Entomologische Nachrichten und Berichte, 7, 143-155.

De Meulemeester, T., Gerbaux, P., Boulvin, M., Coppée, A. \& Rasmont, P. (2011) A simplified protocol for bumble bee species identification by cephalic secretion analysis. Insectes Sociaux,

De Queiroz, K. (2007) Species Concepts and Species Delimitation. Systematic Biology, 56, 879-886.

Dylewska, M. (1966) The Apoidea of the Babia Gora Mountain. Acta Zoologica Cracoviensia, XI, 111175.

Elfving, R. (1968) Die Bienen Finnlands. Fauna Fennica, 21, 1-69.

Engel, M. S. (2011) Systematic melittology: where to from here? Systematic Entomology, 36, 2-15

Estoup, A., Solignac, M., Cornuet, J. M., Goudet, J. \& Scholl, A. (1996) Genetic differentiation of continental and island populations of Bombus terrestris (Hymenoptera: Apidae) in Europe. Molecular Ecology, 5, 19-31.

Farris, J.M., Källersjo, M., Kulge, A. G., Bult, A. C. (1994) Testing significance of incongruence. Cladistics, 10, 315-319.

Felsenstein, J. (1985) Phylogenies and the Comparative Method. The American Naturalist, 125, 1.

Fisher, B. L. \& Smith, M. A. (2008) A Revision of Malagasy Species of Anochetus Mayr and Odontomachus Latreille (Hymenoptera: Formicidae). PLOS ONE, 3(5), e1787. doi:10.1371/journal.pone. 0001787.

Fitzpatrick, U., Murray, T. E., Paxton, R. J. \& Brown, M. J. F. (2006) Regional red data list for Irish Bees. Report for The National Parks and Wildlife Service (Ireland) and Environment and Heritage Service (N. Ireland). 38pp.

Gibbs, J. (2009) Integrative taxonomy indentifies new (and old) species in the Lasioglossum (Dialictus) tegulare (Robertson) species group (Hymenoptera, Halictidae). Zootaxa, 2032, 1-38.

Gloger, C. L. (1833) Das Abändern der Vögel durch Einfluss des Klimas. Breslau, Germany.

Gourbière, S. \& Mallet, J. (2009) Are species real? The shape of the species boundary with exponential failure, reinforcement, and the "missing snowball". Evolution, 64, 1-24.

Grütte, E. (1940) Beitrag zur Kenntnis des Subgenus Allopsithyrus Popov (Hym. Apid.). Deutsche Entomologischen Zeitschrift., 4, 204-223.Haas, A. (1949) Arttypische Flugbahnen von Hummelmännchen. Zeitschrift für vergleichende Physiologie, 31, 281_307.

Haas, A. (1949) Arttypische Flugbahnen von Hummelmännchen. Zeitschrift für vergleichende Physiologie, 31, 281_307.

Haas, A. (1967) Vergleichende Verhaltensstudien zum Paaringsschwarm der Hummeln (Bombus) und Schmarotzerhummeln (Psithyrus). Zeitschrift für Tierpsychologie, 24, 257-277.

Hebert, P. D. N., Ratnasingham, S. \& deWaard, J. R. (2003) Barcoding animal life: cytochrome c oxidase subunit 1 divergences among closely related species. Proceedings of the Royal Society of London Series BBiological Sciences, 270, S96-S99.

Heinrich, B. (1975) Thermoregulation in bumblebees II.
Energetics of warm-up and free flight. Journal of Comparative Physiology, 96, 155-166.

Hillis, D. M. \& Bull, J. J. (1993) An Empirical-Test of Bootstrapping as a Method for Assessing Confidence in Phylogenetic Analysis. Systematic Biology, 42, 182-192.

Hines, H. M. (2008) Historical biogeography, divergence times, and diversification patterns of bumble bees (Hymenoptera : Apidae : Bombus). Systematic Biology, 57, 58-75.

Hines, H. M., Cameron, S. A. \& Williams, P. H. (2006) Molecular phylogeny of the bumble bee subgenus Pyrobombus (Hymenoptera : Apidae : Bombus) with insights into gene utility for lower-level analysis. Invertebrate Systematics, 20, 289-303.

Hoffer, E. (1889) Die Schmarotzerhummeln Steiermarks. Lebensgeschichte und Beschreibung derselben. Mitteilungen Naturwissenschaftlicher Verein Steiermark, 25, 82-158.

Ings, T. C., Ings, N.L., Chittka, L. \& Rasmont, P. (2010) A failed invasion? Commercially introduced pollinators in Southern France. Apidologie, 41, 1-13.

Intoppa, F., Piazza, M. G. \& Riccardelli D'Albore, G. C. (1995) Catalogo bibliografico delle specie di Bombidae (Hymenopetra Apoidae) segnalate per l'Italia. Apicoltura, 10, 1-132

Iserbyt, S. (2009) La faune des bourdons (Hymenoptera : Apidae) du Parc National des Pyrénées occidentales et des zones adjacentes. Annales de la Sociéte Entomologique de France (n.s.), 45, 217-244.

Jordal, B. H. (2002) Elongation Factor 1 alpha resolves the monophyly of the haplodiploid ambrosia beetles Xyleborini (Coleoptera : Curculionidae). Insect Molecular Biology, 11, 453-465.

Katoh, K., Misawa, K., Kuma, K. \& Miyata, T. (2002) MAFFT: a novel method for rapid multiple sequence alignment based on fast Fourier transform. Nucleic Acids Research, 30, 3059-3066.

Kjer, K. M., Blahnik, R. J. \& Holzenthal, R. W. (2001) Phylogeny of Trichoptera (caddisflies): Characterization of signal and noise within multiple datasets. Systematic Biology, 50, 781-816.

Knechtel, W. K. (1955) Fauna Republicy Populare Roumîne. Insecta. Hymenoptera, Subfamilia Apinae. Academia Republicy Populare Roumine, 9, 1-111.

Koulianos, S. \& Schmid-Hempel, P. (2000) Phylogenetic relationships among bumble bees (Bombus, latreille) inferred from mitochondrial cytochrome $\mathrm{b}$ and cytochrome oxidase I sequences. Mol. Phylogenet. Evol., 14, 335-341.

Kullenberg, B., Bergström, G. \& Ställberg-Stenhagen, S. (1970) Volatile components of the cephalic marking secretion of male bumblebees. Acta Chem. Scand., 24, 1481-1483.

Kullenberg, B., Bergström, G., Bringer, B., Carlberg, B. \& Cederberg, B. (1973) Observations on Scent Marking by Bombus Latr. and Psithyrus Lep. Males (Hym., Apidae) and Localization of Site of Production of the Secretion. Zoon, Suppl. 1, 23-30.

Leaché, A. D. \& Fujita, M. K. (2010) Bayesian species delimitation in West African forest geckos (Hemidactylus fasciatus). Procceding of the royal society $B$, (doi:10.1098/rspb.2010.0662)

Lecocq, T. (2009a) Génétique et phéromones sexuelles des bourdons de la Corse. Master thesis. University of Mons. Mons (Belgium).

Lecocq, T., Coppée, A., Michez, D. \& Rasmont, P. 
(2009b) Phylogeny and sexual pheromones of Corsican bumblebees, in Systematics, First meeting of BioSyst EU 2009, Seventh Biennial Conference of the Systematics Association. 14/08/2009, Leiden, Netherlands.

Lhomme, P. (2009) L'inquilinisme chez les bourdons. Osmia, 3, 17-22.

Lockey, K. (1991) Insect hydrocarbon classes implications for chemotaxonomy. Insect Biochemistry, 21, 91-97.

Løken, A. (1984) Scandinavian species of the genus Psithyrus Lepeletier (Hymenoptera: Apidae). Entomologica Scandinavia (supplement), 23, 45 pp.

MacQueen, J. B. (1967) "Some Methods for classification and Analysis of Multivariate Observations, Proceedings of 5-th Berkeley Symposium on Mathematical Statistics and Probability", Berkeley, University of California Press, 1, 281-297.

Maddison, W. \& Maddison, D. (2007) Mesquite: a modular system for evolutionary analysis. Version 2.6 (buid 486).

Maidl, F. (1922) Beiträge zur Hymenopterenfauna Dalmatiens Montenegros und Albaniens. I. Teil: Aculeata und Chrysididae. Ann. Naturhist. Mus, 35, 36-106.

Mantel, N. (1967) The Detection of Disease Clustering and a Generalized Regression Approach. Cancer Research, 27, 209-220.

Martin, S. J., Helanterä, H. \& Drijfhout, F. P. (2008) Evolution of species-specific cuticular hydrocarbon patterns in Formica ants. Biological Journal of the Linnean Society, 95, 131-140.

May, J. (1942) Subgenus Allopsithyrus Popov in Böhmen und Mähren. (Hym. Apid.). Sbornik entom. odd. Zem. Musea v Praze, XX, 223-231.

May, J. (1943) Beitrag zur Systematik einiger arten der schmarotzerhummeln - Psithyrus Lep. (Hymen. Apoid.). Sbornik entom. odd. Zem. Musea v Praze, XXI-XXII, 231-275 + 2 pl.Mayr, E. (1942) Systematics and the Origin of Species. Columbia University Press, New York.

Mayr, E. (1942) Systematics and the Origin of Species. Columbia University Press, New York.

Michener, C. (1951) Subgeneric groups of Hemisia (Hymenoptera, Apoidea). The journalof the kansas entomological society, 24, 1-11

Michez, D. \& Eardley, C. (2007) Monographic revision of the bee genus Melitta Kirby 1802 (Hymenoptera:Apoidea: Melittidae). Annales De La Societe Entomologique De France (n.s.), 43, 379440.

Móczár, M. (1957) Méhfélék, Magyarország állatvilága. Budapest.

Monsevicius, V. (1995) A check-list of wild bee species (Hymenoptera: Apoidea) of Lithuania with data to their distribution and bionomics. in New and Rare for Lithuania insect species. Records and descriptions of 1994-1995. Vilnius.

Müller, M. (1936) Psithyrus barbutellus Kirby und P. maxillosus Klug (Apid., Hym.). Mitteilungen der Deutschen Entomologishen Gesellschaft, 6, 73-76.

Ornosa, G. (1984) La subfamilia Bombinae (Hym., Apidae) de la fauna espanola. PH-D thesis. Universidad Complutense de Madrid. Madrid.

Pagliano, G. (1993) Catalogo Degli Imenotteri Italiani. IV. (Apoidea: Colletidae, Andrenidae, Megachilidae,
Anthophoridae, Apidae). Memorie della Società Entomologica Italiana, 72, 331-467.

Pamilo, P., Tengö, J., Rasmont, P., Pirhonen, K., Pekkarinen, A. \& Kaarnam, E. (1997) Pheromonal and enzyme genetic characteristics of the Bombus lucorum species complex in northern Europe. Entomol.Fenn, 7, 187-194.

Papadopoulou, A., Bergsten, J., Fujisawa, T., Monaghan, M. T., Barraclough, T. G. \& Vogler, A. P. (2008) Speciation and DNA barcodes: testing the effects of dispersal on the formation of discrete sequence clusters. Philosophical Transaction of the Royal Society B, 363, 2987-2996.

Paterson, H. E. H. (1993) Evolution and the recognition concept of species, The Johns Hopkins University Press, $234 \mathrm{pp}$.

Pawlikowski, T. (2008) A distribution atlas of bumblebees of Poland. 104pp

Peat, J., Darvill, B., Ellis, J. \& Goulson, D. (2005) Effects of climate on intra- and interspecific size variation in bumble-bees. Functional Ecology, 19, 145-151.

Pedersen, B. V. (1996) A Phylogenetic Analysis of Cuckoo Bumblebees (Psithyrus, Lepeletier) and Bumblebees (Bombus, Latreille) Inferred from Sequences of the Mitochondrial Gene Cytochrome Oxidase I. Molecular Phylogenetics and Evolution, 5, 289-297.

Pedersen, V. (2002) European bumblebees (Hymenoptera: Bombini)- phylogenetic relationships inferred from DNA sequences. Insect Systematics \& Evolution, 33, 361-386.

Peeters, T. M. J., Raemakers, I. P. \& Smit, J. (1999) Voorlopige atlas van de Nederlandse bijen (Apidae). European Invertebrate Survey, Leiden (Netherland).

Pekkarinen, A. (1982) Morphology and specific status of Bombus lapponicus (Fabricius) and B. monticola Smith (Hymenoptera: Apidae). Entomologica Scandinavia, 13, 41-46.

Pittioni, B. \& Schmidt, R. (1942) Die Bienen des füdöftlichen Niederdonau. 1. Apidae, Podlriidae, Xylocopidae und Certinidae. Niederdonau/Natur und Kultur, 19, 1-69.

Pittioni, B. (1939) Die Hummeln und Schwarotzerhummeln der Balkan-Halbinsel. Mitteilungen aus den Königl. Naturwissenschaftlichen Instituten, XII, 49-115 + VI pl.

Popov, V. B. (1931) Zur Kenntnis der paläarktischen Schmarotzerhummeln (Psithyrus Lep.). Eos, 7, 131209.

Posada, D. (2008) jModelTest: Phylogenetic model averaging. Molecular Biology and Evolution, 25, 1253-1256.

Postner, M. (1952) Biologish-ökologishe untersuchen an Hummeln und ihre Nestern. Veröfentlichungen museum für Naturkunde, 2, 45-86.

Pouvreau, A. (1973) Les ennemis des bourdons. I.- Etude d'une zoocénose : le nid de bourdons. Apidologie, 4, 103-148.

Quinn, G. P. \& Keough, M. J. (2006) Experimental Design and Data analysis for Biologists. Cambridge.

Rambaut, A. \& Drummond, A. (2007) Tracer. v1.5.0.

Rasmont, P. \& Adamski, A. (1996) Les Bourdons de la Corse (Hymenoptera, Apoidea, Bombinae). Notes fauniques de Gembloux, 31, 1-87.

Rasmont, P. \& Flagothier, D. (1996) Biogéographie et choix floraux des bourdons (Hymenoptera, Apidae) 
de la Turquie. N.A.T.O. - O.T.A.N. Tu-Pollination project, rapport préliminaire. Report for Université de Mons Hainaut, Çukurova Universitesi.Mons, Andana Rasmont, P. (1988) Monographie écologique et zoogéographique des bourdons de France et de Belgique (Hymenoptera, Apidae, Bombinae). PH-D thesis. Faculté des Sciences agronomiques de l'Etat. Gembloux (Belgium).

Rasmont, P., Ebmer, P. A., Banaszak, J. \& Zanden, G. v. d. (1995) Hymenoptera Apoidea Gallica. Liste taxonomique des abeilles de France, de Belgique, de Suisse et du Grand-Duché de Luxembourg. Bulletin de la Société de France, 100, 1-98.

Rasmont, P., Terzo, M., Aytekin, A. M., Hines, H., Urbanová, K., Cahliková, L. \& Valterová, I. (2005) Cephalic secretions of the bumblebee subgenus Sibiricobombus Vogt suggest Bombus niveatus Kriechbaumer and Bombus vorticosus Gerstaecker are conspecific (Hymenoptera, Apidae, Bombus). Apidologie, 36, 571-584.

Reinig, W. F. (1935) On the variation of Bombus lapidarius L. and its cuckoo, Psithyrus rupestris Fabr., with notes on mimetic similarity. Journal of genetics, XXX, 321-356.

Reinig, W. F. (1971) Zur Faunistik und Zoogeographie des Vorderen Orients. 3. Beitrag zur Kenntnis der Hummeln und Schmarotzerhummeln Anatoliens. Veröffentlichungen der zoologischen Staatssammlung München, 15, 139-165.

Ressel, F. (1974) Beitrag zur Kenntnis der Hummelfauna des südwestlichen Niederösterreichs (Hym., Apidae). Beitr. Ent., 24, 67-71.

Ronquist, F. \& Huelsenbeck, J. P. (2003) MrBayes 3: Bayesian phylogenetic inference under mixed models. Bioinformatics, 19, 1572-1574.

Schenck, A. (1859) Die nassauischen Bienen. Revision und Ergänzung der früheren Bearbeitungen. Jahrbuch des Nassauischen Vereins für Naturkunde, 14, 1-414.

Schmiedeknecht, H. L. O. (1883) Apidae Europaeae (Die Bienen Europa's) per genera, species et varietates. Dispositae atque descriptae. Volume I fascicule 6, pp. 9(393)-29(413), 1(415)-56(470). Berlin.

Schwarz, M., Gusenleitner, F. \& Kopf T. (2005) Weitere Angaben zur Bienenfauna Österreichs sowie Beschreibung einer neuen Osmia-Art. Vorstudie zu einer Gesamtbearbeitung der Bienen Österreichs VIII. Entomofauna, 26, 117-164.

Schwarz, M. Gusenleitner, F., Westrich, P., \& Dathe, H 100 H. (1996) Katalog der Bienen Österreichs, 1001 Deutschlands und der Schweiz (Hymenoptera, 1002 Apidae). Entomofauna Supplement, 8, 1-398. 1003

Skorikov, A.S., (1922) Faunae Petropolitanae catalogus. 1004 Petrogradskii agronomicheskii institut, 2, 51 pp. 1005

Sladen, F. W. L. (1912) The humble-bee, its life history 1006 and how to domesticate it, with descriptions of all the 1007 British species of Bombus and Psithyrus. London. 1008

Smith, A., Rodriguez, J. J., Whitfield, J. B., Deans, A. R., 1009 Janzen, D. H., Hallwachs, W. \& Hebert, P. D. N. 1010 (2008) Extreme diversity of tropical parasitoid wasps 1011 exposed by iterative integration of natural history, 1012 DNA barcoding, morphology and collections. 1013 Proceeding of the National Academy of Sciences of 1014 the United States of America, 105 (35), 12359-12364. 1015 Straka, J., Bogusch, P. \& Pridal, A. (2007) Apoidea: 1016 Apiformes (včely). Pp. 241-299. In: Bogusch, P., 1017 Straka, J. \& Kment, P. (eds.): Annotated checklist of 1018 the Aculeata (Hymenoptera) of the Czech Republic 1019 and Slovakia. Komentovaný seznam žahadlových blanokřídlých (Hymenoptera: Aculeata) České republiky a Slovenska. Acta Entomologica Musei Nationalis Pragae, Supplementum, 11, 1-300.

Svensson, B. G. \& Bergström, G. (1977) Volatile marking secretions from the labial gland of north European Pyrobombus D.T. males (Hymenoptera, Apidae). Insect Sociaux, 24, 213-224.

Svensson, B. G. (1979) Pyrobombus lapponicus auct. In Europe recognized as two species: $P$. lapponicus (Fabricius, 1793) and P. monticola (Smith, 1849) (Hymenoptera, Apoidea, Bombinae). Entomological Scandinavia, 10, 275-296.

Swofford, D. L. (2001) PAUP*. Phylogenetic Analysis Using Parsimony (*and other methods). 4.0b10. Sinauer Associates, Sunderland, MA.

Symonds, M. R. E., Moussalli, A. \& Elgar, M. A. (2009) The evolution of sex pheromones in an ecologically diverse genus of flies. Biological Journal of the Linnean Society, 97, 594-603.

Tamura, K., Dudley, J., Nei, M. \& Kumar, S. ( 2007) MEGA4: Molecular evolutionary genetics analysis (MEGA) software version 4.0. Molecular Biology and Evolution, 24, 1596-1599.

Templeton, A. R. (1989) The meaning of species and speciation, a genetic perspective. in Speciation and its consequences. (eds Otte D, Endler JA), pp. 3-27. Sinauer, Sunderland, Massachusetts.

Terzo, M., Urbanová, K., Valterová, I.\& Rasmont, P. (2005) Intra and interspecific variability of the cephalic labial glands' secretions in male bumblebees: the case of Bombus (Thoracobombus) ruderarius (Müller) and B. (Thoracobombus) sylvarum (L.) [Hymenoptera, Apidae]. Apidologie, 36, 85-96.

Terzo, M., Valterová, I., Urbanová, K. \& Rasmont, P. (2003) De la nécessité de redécrire les phéromones sexuelles des mâles de bourdons [Hymenoptera, Apidae, Bombini] publiées avant 1996 pour leur utilisation en analyse phylogénétique. Phytoprotection, 84, 39-49.

Tkalců, B. (1969) Ergebnisse der Albanien-Expedition 1961 des Deutschen Entomologischen Institutes. 78. Beitrag. Hymenoptera: Apidae IV (Bombinae). Beiträge zur Entomologie, 19, 887-916.

Trewick, S. A. (2008) DNA barcoding is not enough: mismatch of taxonomy and genealogy in New Zealand grasshoppers (Orthoptera: Acrididae). Cladistics, 24, 240-254.

Tumšs, V. (1975) Materiali Latvijas bišu (Hymenoptera, Apoidea) fauna III. Zoologijas Muzejas Raksti, 13, 524.

Urbanová, K., Halik, J., Hovorka, O., Kindl, J. \& Valterová, I. (2004) Marking pheromones of the cuckoo bumblebee males (Hymenoptera, Apoidea, Bombus Latreille): compositions of labial gland secretions of six species found in the Czech Republic. Biochemical Systematics and Ecology, 32, 10251045.

Valterová, I. \& Urbanová, K. (1997) Chemical signals of bumblebees. Chemicke Listy, 91, 846-857.

Vereecken, N., Mant, J. \& Schiestl, F. P. (2007) Population differentiation in female sex pheromone and male preferences in a solitary bee. Behavioral Ecology and Sociobiology, 61 (4), 811-821.

Vogrin, V. (1955) Prilog fauni Hymenoptera Aculeata Jugoslavije. Zaštita bilja, Beograd, 31, 15-21.

Vogt, O. (1909) Studien über das Artproblem. 1. 
Mitteilung. Über das variieren der Hummeln, 1. Teil. 1052 Naturforschender Freunde, 1, 27- 84.

Voveikov, G.S. (1953) Estestvennaya smena samok vo 1054 cem'ya Schmelej (Hym. Bomb.). Entomologzrheskoe 1055 Obozrenie, 33, 174-181.

Westrich, P. (1989) Die Wildbienen Baden- 1057 Württembergs. Spezieller Teil: Die Gattungen und 1058 Arten. Verlag Eugen Ulmer. Stuttgart, 437-972 1059 pp.Widmer, A., Schimid-Hempel, P., Estoup, A. \& 1060 Scholl, A. (1998) Population genetic structure and 1061 colonization history of Bombus terrestris s.l. 1062 (Hymenoptera: Apidar) from the Canary islands and 1063 Madeira. Heredity, 81, 563-572.

1064

Widmer, A., Schmid-Hempel, P., Estoup, A. \& Scholl, 1065 A. (1998) Population genetic structure and 1066 colonization history of Bombus terrestris s.l. 1067 (Hymenoptera : Apidae) from the Canary Islands and 1068 Madeira. Heredity, 81, 563-572.

1069

Wilcox, T. P., Zwickl, D. J., Heath, T. A. \& Hillis, D. M. 1070 (2002) Phylogenetic relationships of the dwarf boas 1071 and a comparison of Bayesian and bootstrap 1072 measures of phylogenetic support. Molecular 1073 Phylogenetics and Evolution, 25, 361-371.

1074

Williams, P. H. (1985) A preliminary cladistic 1075 investigation of relationships among the bumble bees 1076 (Hymenoptera, Apidae). Systematic Entomology, 10, 1077 239- 255 .

1078

Williams, P. H. (1998) An annotated checklist of bumble 1079 bees with an analysis of patterns of description 1080 (Hymenoptera: Apidae, Bombini). Bulletin of The 1081 Natural History Museum (Entomology), 67, 79-152. 1082 Williams, P. H. (2007) The distribution of bumblebee colour patterns worldwilde: possible significance for thermoregulation, crypsis, and warming mimicry. Biological Journal of the Linnean Society, 92, 97118.

Williams, P. H. (2008) Do the parasitic Psithyrus resemble their host bumblebees in colour pattern? Apidologie, 39, 637-649.

Yassin, A., Cappy, P., Madi-Ravazzi, L., Ogereau, D. \& David, J. R. (2007) DNA barcode discovers two cryptic species and two geographical radiations in the invasive drosophilid Zaprionus indianus. Molecular Ecology Notes, 8, 491-501.

Yefremova, Z. A. (2001) Faunal and ecological notes on species of Bombus Latreille, 1802, and Psithyrus Lepeletier, 1832 (Hymenoptera: Apidae) from the Tarbagatai and Saur mountains ranges in eastern Kazakhstan. Entomologist's Gazette, 52, 269-275.

Žácek, P., Kalinová, B., Šobotník, J., Hovorka, O., Ptacek, V., Coppée, A., Verheggen, J. F. \& Valterová, I. (2009) Comparison of Age-dependent Quantitative Changes in the Male Labial Gland Secretion of Bombus terrestris and Bombus lucorum. Journal of Chemical Ecology, 35, 698-705.

Zhang, Z., Schwartz, S., Wagner, L. \& Miller, W. (2000) A greedy algorithm for aligning DNA sequences. Journal of Computational Biology, 7, 203-214.

Zwickl, D. J. (2006) Genetic algorithm approaches for the phylogenetic analysis of large biological sequence datasets under the maximum likelihood criteria. Ph.D. thesis. The University of Texas at Austin. Austin. 
Table 1. Main morphological and colour pattern differences between B. maxillosus and B. barbutellus males and females according Popov,

\begin{tabular}{|c|c|c|}
\hline Female & B. maxillosus & B. barbutellus \\
\hline \multicolumn{3}{|l|}{ Morphology } \\
\hline $\begin{array}{l}\text { Longest hairs of the posterior } \\
\text { fringe of the hind tibia }\end{array}$ & Shorter than half the largest width of the segment & $\begin{array}{l}\text { Longer than half the largest width of the } \\
\text { segment. }\end{array}$ \\
\hline $\begin{array}{l}\text { Longest hairs of the hind } \\
\text { basitarsus }\end{array}$ & $\begin{array}{l}\text { Shorter than the width of the segment; clearly } \\
\text { narrower at the apex than at the base }\end{array}$ & $\begin{array}{l}\text { Longer than the width of the segment; Its anterior } \\
\text { and posterior edges almost parallel }\end{array}$ \\
\hline Coat & Short & Long and shaggy \\
\hline \multicolumn{3}{|l|}{ Colour pattern } \\
\hline Wings & Darkened, almost opaque & Hyaline \\
\hline Collare and scutellare & Narrower, mixed with black hairs & Very wide, yellow \\
\hline $\mathrm{T} 1$ & Black & Yellow mixed with black \\
\hline $\mathrm{T} 4$ & Off-white & With white sides \\
\hline T5 & With off-white sides & White \\
\hline \multicolumn{3}{|l|}{ Male } \\
\hline \multicolumn{3}{|l|}{ Morphology } \\
\hline $\begin{array}{l}\text { Longest hairs of the anterior } \\
\text { fringe on the hind basitarsus }\end{array}$ & Shorter than the width of the segment & $\begin{array}{l}\text { As long as, or slightly longer than the width of } \\
\text { the segment }\end{array}$ \\
\hline Coat & Short & Shaggy \\
\hline \multicolumn{3}{|l|}{ Colour pattern } \\
\hline Wings & Darkened & Hyaline \\
\hline Vertex & With a few yellowish hairs & With a few yellow hairs \\
\hline Collare and scutellare & $\begin{array}{l}\text { Narrower, yellowish, often mixed with many } \\
\text { black hairs }\end{array}$ & Wide, yellow \\
\hline $\mathrm{T} 1$ & Either black or yellowish, mixed with black hairs & Yellow \\
\hline $\mathrm{T} 3$ & With off-white sides & With white posterior margins \\
\hline T5 & With off-white sides & With white posterior margins \\
\hline T6 & With small off-white tuft on its side & With white sides \\
\hline
\end{tabular}

Table 2. Host/parasite relations in the Allopsithyrus group. Main hosts are in bold.(*): Colonies in which Psithyrus offspring have been

\begin{tabular}{lll} 
& \multicolumn{1}{c}{ observed } \\
\hline Allopsithyrus & Bombus Host species & Main references \\
\hline B. barbutellus & B. (Megabombus) hortorum* & Sladen 1912; Ball 1914; Müller 1936; Cumber 1949; Postner 1952 \\
& B. (Megabombus) ruderatus & Westrich 1989; Peeters et al., 1999 \\
& B. (Megabombus) portschinsky & Rasmont unpublished data \\
& B. (Pyrobombus) hypnorum* & Voveikov 1953; Pouvreau 1973 \\
& B. (Pyrobombus) jonellus & Schenck 1859; Schmiedekneht 1883; Skorikov 1922 \\
& B. (Pyrobombus) pratorum & Hoffer 1889; Skorikov 1922 \\
& B. (Thoracobombus) pascuorum & Hoffer 1889; Skorikov 1922; Popov 1931 \\
& B. (Thoracobombus) humilis & Hoffer 1889; Skorikov 1922 \\
& B. (Thoracobombus) ruderarius & Skorikov 1922 \\
& B.(Subterraneobombus) distinguendus & Popov 1931 \\
& B.(Subterraneobombus) subterraneus & Knechtel 1955 \\
& & \\
& & \\
& B. (Megabombus) ruderatus & Vogt 1909; Popov 1931; Pittioni \& Schmidt 1942; Rasmont 1988 \\
& B. (Megabombus) argillaceus & Popov 1931; Skorikov 1922; Pittioni \& Schmidt 1942; Pouvreau 1973 \\
B.(Subterraneobombus) subterraneus & Tkalcü 1969; Pouvreau 1973 \\
\hline
\end{tabular}


Table 3. Allopsithyrus and outgroup taxa examined, their collection locality, collector, vouchers numbers and GenBank accession numbers. \# = number of samples; V.\# = voucher numbers and sample codes used in

\begin{tabular}{|c|c|c|c|c|c|c|c|c|c|c|}
\hline & Species & Subspecies & $\#$ & Locality & Lat & Long & Recorder & $\begin{array}{l}\text { V.\# } \\
\end{array}$ & EF-1a & COI \\
\hline \multirow[t]{13}{*}{ Ingroup } & barbutellus & - & 7 & Turkey, Rize & $40^{\circ} 56^{\prime} 01^{\prime \prime} \mathrm{N}$ & $41^{\circ} 08^{\prime} 26^{\prime \prime} \mathrm{E}$ & M. Terzo \& P. Rasmont & $\begin{array}{c}\text { BAR1, BAR2, BAR4, } \\
\text { BAR5, BAR6, BAR8, } \\
\text { BAR9 }\end{array}$ & JF699169 & JF699183 \\
\hline & barbutellus & - & 1 & Sweden, Uppsala & $59^{\circ} 51^{\prime} 15^{\prime \prime} \mathrm{N}$ & $17^{\circ} 39^{\prime} 14^{\prime \prime} \mathrm{E}$ & P. Rasmont & BAR3 & JF699171 & JF699185 \\
\hline & barbutellus & - & 1 & Germany, Rottleberode & $51^{\circ} 31^{\prime} 43^{\prime \prime} \mathrm{N}$ & $10^{\circ} 57^{\prime} 08^{\prime \prime} \mathrm{E}$ & E. Stolle & BAR7 & JF699172 & JF699186 \\
\hline & barbutellus & - & 4 & France, Ablon & $49^{\circ} 23^{\prime} 38^{\prime \prime} \mathrm{N}$ & $0^{\circ} 17{ }^{\prime} 43^{\prime \prime} \mathrm{E}$ & P. Lhomme & $\begin{array}{l}\text { BAR10, BAR11, } \\
\text { BAR12, BAR13 }\end{array}$ & JF699170 & JF699184 \\
\hline & barbutellus & - & 1 & Denmark, Ekkodalen & - & - & Pedersen (2002) & BAR14 & - & AY181177.1 \\
\hline & barbutellus & - & 1 & Germany, Tüchersfeld & - & - & Pedersen (2002) & BAR15 & - & AY181176.1 \\
\hline & barbutellus & - & 1 & Denmark & - & - & Pedersen (1996) & BAR17 & - & L26574.1 \\
\hline & barbutellus & - & 1 & Russia, Primorsky & - & - & Tanaka et al. (unpublished) & BAR16 & - & AF279576.1 \\
\hline & maxillosus & maxillosus & 4 & Turkey, Kayseri & $38^{\circ} 28^{\prime} 36^{\prime \prime} \mathrm{N}$ & $35^{\circ} 30^{\prime} 06^{\prime \prime} \mathrm{E}$ & M. Terzo & $\begin{array}{l}\text { MAX1, MAX3, } \\
\text { MAX5, MAX6 }\end{array}$ & JF699176 & JF699190 \\
\hline & maxillosus & maxillosus & 3 & Turkey, Erzincan & $39^{\circ} 52^{\prime} 06^{\prime \prime} \mathrm{N}$ & $39^{\circ} 33^{\prime} 56^{\prime \prime} \mathrm{E}$ & $\begin{array}{l}\text { T. De Meulemeester \& P. } \\
\text { Rasmont }\end{array}$ & MAX7, MAX8, MAX9 & JF699179 & JF699193 \\
\hline & maxillosus & maxillosus & 2 & France, Gonfaron & $43^{\circ} 18^{\prime} 28^{\prime \prime} \mathrm{N}$ & $06^{\circ} 18^{\prime} 33^{\prime \prime} \mathrm{E}$ & P. Rasmont & MAX2, MAX4 & JF699178 & JF699192 \\
\hline & maxillosus & maxillosus & 1 & France, Bargemon & $43^{\circ} 38^{\prime} 22^{\prime \prime} \mathrm{N}$ & $06^{\circ} 34^{\prime} 07^{\prime \prime} \mathrm{E}$ & P. Rasmont & MAX10, MAX11 & JF699177 & JF699191 \\
\hline & maxillosus & italicus & 3 & France, Evisa & $42^{\circ} 17^{\prime} 25^{\prime \prime} \mathrm{N}$ & $08^{\circ} 52^{\prime} 40^{\prime \prime} \mathrm{E}$ & T. Lecocq & ITA1, ITA2, IT3 & JF699175 & JF699189 \\
\hline \multirow[t]{5}{*}{ Outgroup } & campestris & campestris & 2 & France, Saint-Lyphard & $47^{\circ} 23^{\prime} 52^{\prime \prime} \mathrm{N}$ & $02^{\circ} 18^{\prime} 24^{\prime \prime W}$ & G. Mahé & CAM1, CAM2 & JF699174 & JF699188 \\
\hline & bohemicus & bohemicus & 2 & France, Nyer & $42^{\circ} 30^{\prime} 06^{\prime \prime} \mathrm{N}$ & $02^{\circ} 19^{\prime} 00^{\prime \prime} \mathrm{E}$ & T. Lecocq & BOH1, BOH2 & JF699173 & JF699187 \\
\hline & rupestris & rupestris & 2 & Germany, Geiseltal & $51^{\circ} 18^{\prime} 00^{\prime \prime} \mathrm{N}$ & $11^{\circ} 52^{\prime} 00^{\prime \prime} \mathrm{E}$ & E. Stolle & RUP1, RUP2 & JF699180 & JF699194 \\
\hline & vestalis & vestalis & 2 & France, Paris & $48^{\circ} 50^{\prime} 37^{\prime \prime} \mathrm{N}$ & $02^{\circ} 21^{\prime} 35^{\prime \prime E}$ & P. Rasmont & VES1, VES2 & JF699182 & JF699196 \\
\hline & soroeensis & lectitatus & 1 & France, Nyer & $42^{\circ} 30^{\prime} 09^{\prime \prime N}$ & $02^{\circ} 19^{\prime} 12^{\prime \prime} \mathrm{E}$ & T. Lecocq & SOR1 & JF699181 & JF699195 \\
\hline
\end{tabular}


Table 4. List of the identified compounds. Molecular weight (MW $[\mathrm{m} / z])$, Median (Med [\%]), first and fourth quartiles (Q1 [\%] and Q2 [\%]), minimum and maximum (Min [\%]and Max [\%]) of the 73 identified compounds in B. barbutellus, B. maxillosus maxillosus and B. maxillosus italicus. The undetermined compounds are indicated as Ux.

\begin{tabular}{|c|c|c|c|c|c|c|c|c|c|c|c|}
\hline \multirow{2}{*}{ Compounds } & \multirow{2}{*}{ MW } & \multicolumn{5}{|c|}{ B. barbutellus } & \multicolumn{5}{|c|}{ B. maxillosus } \\
\hline & & Min & Q1 & Med & Q3 & Max & Min & Q1 & Med & Q3 & Max \\
\hline Decanoic acid & 172 & 0,01 & 0,02 & 0,02 & 0,02 & 0,15 & 0 & 0,02 & 0,02 & 0,05 & 0,15 \\
\hline Geranyl acetone & 194 & 0,01 & 0,02 & 0,02 & 0,15 & 0,2 & 0 & 0,02 & 0,03 & 0,05 & 0,2 \\
\hline Tetradecane & 198 & 0,27 & 0,36 & 0,75 & 1,58 & 3,49 & 0 & 1,43 & 2,3 & 2,85 & 4,12 \\
\hline Dodecanoic acid & 200 & 0,01 & 0,02 & 0,03 & 0,16 & 2,72 & 0,01 & 0,05 & 0,3 & 1,83 & 5,15 \\
\hline Farnesal, isomer I & 220 & 0,04 & 0,12 & 0,18 & 0,21 & 0,31 & 0 & 0,05 & 0,16 & 0,33 & 0,61 \\
\hline Farnesal, isomer II & 220 & 0,14 & 0,29 & 0,36 & 0,45 & 0,59 & 0 & 0,1 & 0,23 & 0,63 & 0,92 \\
\hline Farnesol & 222 & 0,03 & 0,05 & 0,1 & 0,2 & 0,37 & 0 & 0 & 0,21 & 0,47 & 1,54 \\
\hline Dihydrofarnesol & 224 & 0,13 & 0,2 & 0,38 & 0,42 & 0,53 & 0 & 0,08 & 0,15 & 0,24 & 0,53 \\
\hline Ethyl dodecanoate & 228 & 0 & 0,02 & 0,02 & 0,07 & 0,15 & 0 & 0 & 0,01 & 0,02 & 0,15 \\
\hline Tetradecenoic acid & 228 & 0 & 0 & 0,02 & 0,03 & 0,04 & 0 & 0,01 & 0,04 & 0,1 & 0,16 \\
\hline Heptadecane & 240 & 0 & 0,01 & 0,02 & 0,02 & 0,06 & 0 & 0,01 & 0,02 & 0,05 & 0,15 \\
\hline Ethyl tetradecenoate & 254 & 0 & 0 & 0 & 0,01 & 0,07 & 0 & 0,02 & 0,1 & 0,25 & 19 \\
\hline Hexadecenoic acid & 254 & 0 & 0,03 & 0,16 & 0,21 & 0,76 & 0 & 0,2 & 0,35 & 0,44 & 1,69 \\
\hline Ethyl tetradecanoate & 256 & 0 & 0 & 0 & 0,01 & 0,01 & 0 & 0 & 0,02 & 0,11 & 0,79 \\
\hline Farnesyl acetate & 264 & 10,21 & 11,35 & 16,58 & 20,98 & 37,89 & 0,19 & 20,84 & 25,53 & 28,37 & 45,4 \\
\hline Octadecenal & 266 & 0,02 & 0,03 & 0,04 & 0,06 & 0,6 & 0 & 0,08 & 0,32 & 0,55 & 1,93 \\
\hline Dihydrofarnesyl acetate & 266 & 0,09 & 0,29 & 0,49 & 0,64 & 0,82 & 0 & 0,1 & 0,31 & 0,89 & 1,7 \\
\hline Octadecanal & 268 & 0 & 0 & 0,01 & 0,01 & 0,13 & 0 & 0,02 & 0,07 & 0,13 & 0,32 \\
\hline Octadecenol & 268 & 11,81 & 13,23 & 16,17 & 20,68 & 24,28 & 0,02 & 2,25 & $\mathbf{9 , 5 8}$ & 13,94 & 24,28 \\
\hline Ethyl hexadecenoate & 282 & 0 & 0 & 0 & 0,01 & 0,02 & 0 & 0,03 & 0,04 & 0,18 & 0,47 \\
\hline Octadecenoic acid & 282 & 0 & 0,02 & 0,07 & 0,15 & 0,61 & 0 & 0,01 & 0,13 & 0,22 & 1,95 \\
\hline Ethyl hexadecanoate & 284 & 0,01 & 0,03 & 0,06 & 0,08 & 0,22 & 0 & 0,04 & 0,15 & 0,36 & 0,79 \\
\hline Geranylgeranial & 288 & 0,14 & 0,33 & 0,46 & 0,48 & 1,04 & 0 & 0,12 & 0,19 & 0,23 & 1,04 \\
\hline Farnesyl butyrate & 292 & 0 & 0 & 0,18 & 0,5 & 0,9 & 0 & 0,26 & 0,63 & 0,83 & 2,33 \\
\hline Geranylcitronellol & 292 & 1,54 & 2,6 & 3,25 & 3,69 & 6,34 & 0,12 & 1,49 & 2,04 & 2,4 & 6,61 \\
\hline Heneicosene & 294 & 0 & 0 & 0,03 & 0,66 & 4,85 & 0 & 0,12 & 0,33 & 0,81 & 4,72 \\
\hline Heneicosane & 296 & 0,3 & 0,77 & 0,97 & 1,54 & 1,68 & 0,02 & 0,11 & 0,15 & 0,17 & 1,68 \\
\hline Eicosenol & 296 & 0 & 0 & 0 & 0 & 9,03 & 0 & 0 & 4,22 & 4,73 & 9,03 \\
\hline Octadecenoic acid ethyl ester & 310 & 0 & 0 & 0 & 0,08 & 0,08 & 0 & 0 & 0,03 & 0,09 & 0,44 \\
\hline Octadecenyl acetate & 310 & 0,75 & 0,85 & 0,9 & 1,05 & 2,12 & 0,4 & 0,93 & 1,04 & 1,1 & 2,04 \\
\hline Docosane & 310 & 0 & 0,14 & 0,16 & 0,18 & 0,22 & 0 & 0,11 & 0,15 & 0,21 & 0,25 \\
\hline Tricosene & 322 & 0,08 & 0,1 & 0,19 & 0,21 & 0,33 & 0 & 0,02 & 0,18 & 0,23 & 0,54 \\
\hline Tricosane & 324 & 0,04 & 0,18 & 6,19 & 7,51 & 9,91 & 0,02 & 0,07 & 0,11 & 0,14 & 10,91 \\
\hline decanoylglycerol & 330 & 0 & 0,17 & 0,68 & 7,72 & 14,32 & 0 & 0,3 & 0,47 & 1,14 & 15,6 \\
\hline Geranylcitronellyl acetate & 334 & 0,12 & 0,46 & 0,51 & 0,98 & 1,47 & 0,2 & 0,57 & 0,67 & 0,82 & 2,87 \\
\hline Eicosenyl acetate & 338 & 0,03 & 0,17 & 0,31 & 0,35 & 0,8 & 0,04 & 0,07 & 0,1 & 0,19 & 2,61 \\
\hline Tetracosane & 338 & 0,04 & 0,04 & 0,07 & 0,08 & 0,49 & 0 & 0,04 & 0,06 & 0,08 & 0,49 \\
\hline Eicosyl acetate & 340 & 0 & 0 & 0 & 0,01 & 0,18 & 0 & 0,01 & 0,02 & 0,03 & 0,22 \\
\hline Pentacosene I & 350 & 0,02 & 0,04 & 0,07 & 0,1 & 0,23 & 0,01 & 0,03 & 0,05 & 0,09 & 3,62 \\
\hline Pentacosene II & 350 & 0,04 & 0,08 & 0,11 & 0,17 & 0,28 & 0,02 & 0,05 & 0,08 & 0,11 & 0,28 \\
\hline Pentacosane & 352 & 1,17 & 1,7 & 1,96 & 2,15 & 4,66 & 0,76 & 1,18 & 1,6 & 1,85 & 4,66 \\
\hline $\begin{array}{l}\text { 1,3-Diacetyl-2- } \\
\text { dodecanoylglycerol }\end{array}$ & 358 & 8,72 & 16,83 & 25,11 & 26,86 & 31,11 & 0,96 & 10,85 & 19,02 & 24,08 & 31,11 \\
\hline
\end{tabular}




\begin{tabular}{|c|c|c|c|c|c|c|c|c|c|c|c|}
\hline Hexacosene & 364 & 0,02 & 0,02 & 0,04 & 0,08 & 0,12 & 0,01 & 0,01 & 0,02 & 0,04 & 0,12 \\
\hline Farnesyl decanoate & 376 & 0,04 & 0,07 & 0,08 & 0,13 & 0,2 & 0,05 & 0,06 & 0,08 & 0,22 & 0,38 \\
\hline Heptacosene, isomer I & 378 & 0 & 0,03 & 0,04 & 0,1 & 0,22 & 0,01 & 0,03 & 0,05 & 0,09 & 3,01 \\
\hline Heptacosene, isomer II & 378 & 0,05 & 0,27 & 0,37 & 0,59 & 1,08 & 0,07 & 0,13 & 0,27 & 0,45 & 1,08 \\
\hline Heptacosane & 380 & 0,52 & 0,83 & 1,06 & 1,63 & 3,34 & 0,61 & 0,8 & 0,94 & 1,49 & 4,11 \\
\hline Hexacosenol & 380 & 0,04 & 0,09 & 0,12 & 0,17 & 0,35 & 0 & 0,04 & 0,12 & 0,23 & 0,35 \\
\hline $\begin{array}{l}\text { Hexacosanol } \\
\text { 1,3-Diacetyl-2- }\end{array}$ & 382 & 0,02 & 0,05 & 0,05 & 0,13 & 0,32 & 0,01 & 0,02 & 0,06 & 0,12 & 1,55 \\
\hline & 384 & 0 & 0,23 & 0,37 & 0,45 & 0,53 & 0,04 & 0,22 & 0,91 & 1,74 & 2,58 \\
\hline tetradecanoylglycerol & 386 & 0,04 & 0,08 & 0,13 & 0,15 & 0,19 & 0 & 0,05 & 0,18 & 0,35 & 1,12 \\
\hline Octadecenyl octanoate & 394 & 0,02 & 0,03 & 0,05 & 0,07 & 0,09 & 0,01 & 0,03 & 0,05 & 0,08 & 0,19 \\
\hline Hexadecyl decanoate & 396 & 0,03 & 0,04 & 0,05 & 0,07 & 0,33 & 0 & 0,01 & 0,02 & 0,07 & 0,33 \\
\hline Farnesyl dodecanoate & 404 & 0,07 & 0,08 & 0,1 & 0,24 & 0,69 & 0,02 & 0,15 & 0,38 & 1,36 & 4,41 \\
\hline Nonacosene & 406 & 0,04 & 0,07 & 0,12 & 0,16 & 0,21 & 0,03 & 0,04 & 0,08 & 0,14 & 0,27 \\
\hline Nonacosane & 408 & 0,1 & 0,16 & 0,2 & 0,25 & 0,72 & 0,11 & 0,15 & 0,18 & 0,26 & 0,76 \\
\hline $\begin{array}{l}\text { Squalene } \\
\text { 1,3-Diacetyl-2- }\end{array}$ & 410 & 0 & 0 & 0,01 & 0,01 & 0,02 & 0 & 0,01 & 0,01 & 0,03 & 0,09 \\
\hline hexadecanoylglycerol & 412 & 0 & 0 & 0 & 0 & 0,13 & 0 & 0 & 0 & 0 & 0,13 \\
\hline Octadecenyl decanoate & 422 & 0,09 & 0,19 & 0,28 & 0,38 & 1,79 & 0,05 & 0,13 & 0,42 & 0,95 & 3,35 \\
\hline Hexadecyl dodecanoate & 424 & 0,01 & 0,03 & 0,04 & 0,09 & 0,16 & 0 & 0,02 & 0,08 & 0,13 & 0,24 \\
\hline Hentriacontene & 434 & 0,02 & 0,02 & 0,03 & 0,06 & 0,08 & 0,01 & 0,02 & 0,04 & 0,07 & 0,16 \\
\hline Geranylcitronellyl decanoate & 446 & 0 & 0,01 & 0,02 & 0,04 & 0,25 & 0 & 0,01 & 0,02 & 0,07 & 0,61 \\
\hline Octadecenyl dodecanoate & 450 & 1,53 & 2,61 & 3,64 & 7,04 & 10,08 & 0,58 & 2,51 & 7,4 & 13,93 & 20,94 \\
\hline Farnesyl hexadecanoate & 460 & 0 & 0,01 & 0,01 & 0,12 & 0,46 & 0 & 0 & 0,09 & 0,3 & 0,93 \\
\hline Geranylcitronellyl dodecanoate & 474 & 0,14 & 0,16 & 0,19 & 1,21 & 1,76 & 0,02 & 0,14 & 0,33 & 1,75 & 3,93 \\
\hline Eicosenyl dodecanoate & 478 & 0,74 & 0,88 & 1,3 & 2,03 & 3,64 & 0,3 & 0,72 & 1,61 & 4,72 & 12,06 \\
\hline Farnesyl octadecenoate & 486 & 0 & 0 & 0 & 0,06 & 0,12 & 0 & 0,04 & 0,06 & 0,08 & 0,5 \\
\hline U1 & MW? & 0,26 & 0,4 & 3,51 & 7,37 & 9,87 & 0 & 2,67 & 3,61 & 3,88 & 9,87 \\
\hline $\mathrm{U} 2$ & MW? & 0,01 & 0,07 & 0,09 & 0,18 & 0,35 & 0 & 0,09 & 0,15 & 0,21 & 2,68 \\
\hline U3 & MW? & 0 & 0,02 & 0,03 & 0,04 & 2,89 & 0 & 0 & 0,01 & 0,03 & 2,89 \\
\hline U4 & MW? & 0,03 & 0,05 & 0,06 & 0,1 & 0,18 & 0 & 0,03 & 0,08 & 0,1 & 0,21 \\
\hline U5 & MW? & 0,01 & 0,02 & 0,02 & 0,03 & 0,04 & 0,01 & 0,03 & 0,07 & 0,14 & 0,59 \\
\hline U6 & MW? & 0,01 & 0,01 & 0,01 & 0,02 & 0,11 & 0 & 0,01 & 0,03 & 0,05 & 0,41 \\
\hline
\end{tabular}

